\title{
A step forward in tropical anthracology: understanding woodland vegetation and wood uses in ancient Sri Lanka based on charcoal records from Mantai, Kirinda and Kantharodai
}

\author{
Ethel Alluéa,b, Charlene Murphy ${ }^{\mathrm{c}}$, Eleanor Kingwell-Banham ${ }^{\mathrm{c}}$, Wijerathne Bohingamuwa ${ }^{\mathrm{d}}$, \\ Gamini Adikarie, Nimal Perera ${ }^{\mathrm{f}}$, Nicole Boivin ${ }^{\mathrm{g}, \mathrm{h}, \mathrm{i}, \mathrm{j}}$, Dorian Q. Fuller ${ }^{\mathrm{c}, \mathrm{g}, \mathrm{k}}$ \\ a. IPHES, Institut Català de Paleoecologia Humana i Evolució Social, Zona Educacional 4 Campus \\ Sescelades URV (Edifici W3), 43007-Tarragona, Spain. \\ b. À̀rea de Prehistòria, Universitat Rovira i Virgili (URV), Av. Catalunya 35, 43002- Tarragona, Spain. \\ c. University College London, Institute of Archaeology, 31-34 Gordon Square, WC1H 0PY London, UK \\ d. Department of History and Archaeology, University of Ruhuna, Wellmadama, Matara, Sri Lanka \\ e. Postgraduate Institute of Archaeology, No. 407 Bauddhaloka Mawatha, Colombo 00700, Sri Lanka \\ f. Department of Archaeology. Government of Sri Lanka, Colombo, Sri Lanka \\ g. Department of Archaeology, Max Planck Institute for the Science of Human History, Jena, Germany \\ h. School of Social Science, The University of Queensland, St Lucia, Australia \\ i. Department of Anthropology and Archaeology, University of Calgary, Calgary, Canada. \\ j. Department of Anthropology, National Museum of Natural History, Smithsonian Institution, \\ Washington, DC, USA. \\ k. School of Cultural Heritage, North West University, Xi'an, Shaanxi, China
}

\begin{abstract}
The aim of this study is to present the anthracological results from three archaeological sites located in the North, North West and South East of Sri Lanka. The study is based on the observation and analysis of 1689 charcoal fragments using for support the reference collection of South Indian wood at the Institute of Archaeology ( UCL), Inside Wood (2004onwards) and several wood anatomy atlases. Mantai (200 BCE-850 CE), an urban site, has yielded 25 taxa with significant presence of cf. Cocos nucifera among other taxa.

Kantharodai (400-170- BCE), an urban site, has yielded 19 taxa from arid zones (Fabaceae, Rubiaceae), mangroves (Rhizophoraceae) and dune zones (cf. Cocos nucifera). Kirinda (500$900 \mathrm{CE}$ ), a fishing settlement, has yielded 24 taxa including Fabaceae (Dalbergia, Acacia) and Rubiaceae, belonging to dry deciduous forest and open savannas. This collective data set allows for the identification of discernible patterns related to the use of ecological interfaces between the forest and the open plains, used and actively managed by humans, and the possibility to identify if this changed with an increase in maritime trade and/or changes in agriculture over time. This study provides evidence of the differences in the vegetation present as well as use of wood fuel and other specific uses of wood for each site examined. It also sheds new light on tropical anthracology regarding quantification and accuracy in taxa identification.
\end{abstract}

Keywords Vegetation, Wood uses, Fuel, Landscape transformation, Tropical anthracology 


\section{Introduction}

Tropical areas represent over $40 \%$ of the world's surface. In these areas, research in archaeology has been carried out unevenly, largely according to the countries' socioeconomic and political situations and specific scientific issues (see Stahl 2004; Mercader et al., 2002; Higham, 1996; Dotte-Sarout, 2017). Archaeobotany (seed/fruit, phytolith) research is generally focused on aspects related to agricultural origins and early domestication with efforts focused in certain regions and select staple/plant evidence providing synthetic overviews on these key issues (Kajale, 1991; Hather, 1994; Fuller et al., 2004; Murphy and Fuller, 2017; Pearsall, 2019; Höhn, 2018). Anthracology, is perhaps the least studied of the applied environmental archaeological sub-disciplines, especially in tropical regions. Some fairly recent anthracological studies have been undertaken regionally in South America (Scheel-Ybert, 2000, Scheel-Ybert, 2002, Scheel-Ybert et al., 2014; Martín-Seijo et al., 2020), Southeast Asia (Thompson, 1994); Oceania and Australia (Dotte-Sarout, 2010, 2011; Dotte-Sarout et al., 2013, Dotte-Sarout et al., 2015, Dotte-Sarout and Kahn, 2017) and Africa ( Neumann 1992; Höhn, 2007, 2018; Neumann et al., 2012; Höhn and Neumann, 2018; Eichhorn and Neumann, 2016, Höhn et al., 2018). Other encouraging charcoal research is preliminary studies which have specific analyses contributing to the site's environmental archaeological approach (see Lancelotti, 2018, Lancelotti et al., 2013, Mvimi, 2019; King and Dotte-Sarout, 2019; Ekblom et al., 2014; Bodin et al., 2019; Franke et al., 2020; Byrne et al., 2020). The International meeting of anthracology has seen the development of studies on tropical areas by several groups and/or individuals working in different areas throughout the world. The number of studies in these tropical regions has been fluctuating from 0 to 3 (Vernet, 1992; Thiébault, 2002; Fiorentino and Magri, 2008; Damblon, 2013; Badal et al., 2012; Ludemann and Nelle, 2017a ;2017b; 2018; Asouti, 2019). The low number of studies in tropical areas is likely related to the fact that the conference has only been held in Europe and focuses on charcoal research being carried out in Europe or Western Asia. The current paper reports the first archaeological wood charcoal study from flotation carried out in Sri Lanka.

Sri Lankan flora is extremely important as a source of plants for multiple purposes including food, fuel, craft, timber, technology, and medicine for humans (Willis 1915; Perera 1975, 2012). Also, Sri Lanka's geographic position and topography have influenced early human dispersals and the island's occupation into historical times as an important entrepôt for the growing routes within the Indian Ocean from Africa and Europe to Asia (Fuller et al., 2011, Fuller and Murphy, 2018; Muthucumarana et al., 2014; Seland, 2014; Roberts et al., 2015, 2016, 2017; Boivin et al., 2017; Bohingamuwa, 2017,2018). Sri Lanka's limited archaeobotanical and isotopic record, based on cave sites from hunter-gatherer-foraging contexts, investigated to date shows evidence of a fairly broad spectrum of plants and animals being exploited at the interface between ecozones (Roberts et al., 2015, 2017). In later periods, with the development of agriculture, sedentism and urbanization one would expect to see an increase in the local impact upon woodland resources, increased potential for transport of wood and demands of wood resources for particular purposes such as charcoal for pyrotechnic activities.

During recent decades, in southern India and nearby territories, systematic archaeobotanical sampling has been carried out by local and international research groups (Kajale, 1994; Fuller, 2002, 2008; Fuller et al., 2004, 2007; Fuller and Murphy, 2014; Weisskopf et al., 2014; Fuller and Harvey, 2006; Roberts et al., 2016; Kingwell-Banham, 2019). Sri Lankan archaeobotanical research is limited at the moment but increasing over recent years with the 
development of related projects (Kajale, 1989, 1990, 1994; Premathilake et al., 1999; Premathilake, 2006; Premathilake and Seneviratne, 2015; Adikari, 2009; Murphy et al., 2018; Kingwell-Banham et al., 2018). This research has focused on the domestication, spread of cultivars and changes in agricultural techniques (rainfed, irrigation), all of which represent important changes in the relationship of human groups and societies with their ecosystems.

Anthracology, can shed new insights into several of these aspects mentioned above, however, studies are still limited in this region to date (Lancelotti, 2018; Demicoli, 2015). The creation of an atlas by Asouti and Fuller (2008) is an essential tool for this purpose and has put in place the first steps in the development of anthracology as a discipline in this region.

Human occupation in Sri Lanka from the late Pleistocene is related to environmental changes and the expansion of Homo sapiens into new territories (Deraniyagala, 2004; Perera et al., 2011). As in southern Indian contexts, hunting and gathering coexisted with alternative livelihood strategies, such as grazing, extensive and intensive agricultural practices, fishing and marine resource collection and trade in Sri Lanka. Therefore, different communities and economic subsistence strategies were established in Sri Lanka during the initial historical period (Siriweera, 2004; Morrison 2016). This fact is inevitably related to transformations of forest exploitation strategies to obtain various resources and the need for fuel related to the increase in diversity and intensity of domestic activities. According to the existing records to date, firewood is the fuel used throughout prehistoric and historical periods in Sri Lanka due to its availability in the majority of ecological regions.

The fuel requirements were probably different according to the site's function and in this project we obtained results related to the economic aspects on the use of energy resources in different type of historical settlements including a fishing settlement and two urban sites. Thus, the anthracological data allows for the identification of the existence of a direct and active management of fuel by human groups, an element that increases the complexity of societal-natural resource usage and socio-environmental relationships in which energy consumption is situated and can be quantified. This data can highlight the effects on the landscapes based upon these new management practices, as well as the first evidence of management and sustainable exploitation of forests.

This study presents the first results of a systematic anthracological study of three historical sites from different coastal areas of Sri Lanka. The anthracological evidence from the sites of Kirinda, Kantharodai and Mantai allows for the characterization of vegetal communities, wood uses and woodland transformations at these communities between ca. $200 \mathrm{BCE}$ and CE 900 (Fig. 1, Fig. 2).

\section{Biogeographical and archaeological context}

Sri Lanka is characterized by different major climatic regions that allow the development of several vegetal communities (Dittus, 1977, Dittus, 1985, Ashton et al., 1997) (Fig. 1a and b). The wet zone receives rain from both monsoons and are characterized by deciduous wet tropical forests including a large diversity of species from both highlands and lowlands forests. The intermediate zone, in between the wet and dry zones is characterized by dry evergreen and deciduous forests. The dry zone receives rain from only one monsoon and is 
characterize by dry semi-evergreen forests and savanna vegetation (Dittus, 1977). In coastal areas mangroves are developed in marshy areas (Ashton et al., 1997, Dittus, 1985) (Fig. 1b).

The coastal sites of Kirinda, Kantharodai and Mantai are all located in the Dry/Arid Zone (the Eco-zone F in Deraniyagala (1992, 2004) (Fig. 1a and b, Fig. 2). Kirinda is located on the southeast coast and is classified as a fishing harbour dated to 500-900 CE (Bohingamuwa 2017; Murphy et al., 2018) (Fig. 2). Kantharodai and Mantai were both active ports from early historical times. However, trade at Kantharodai decreased with the corresponding increase in trade at Mantai in the middle Historic period (Murphy et al., 2018). Kantharodai, located on the northern coast is one of the four largest urban and religious centres in Sri Lanka during the Early Historic period. There is some early evidence for its foundation from the Proto-historic Early Iron Age, however, the first settlement is dated to the beginning of the Early Historic Period (ca. 170-500-BCE) (Coningham and Strickland, 2008; Bohingamuwa 2017; Murphy et al., 2018). Mantai, was the main port entrance to the capital Anuradhapura, during the Historic Period, located $80 \mathrm{~km}$ south of the city (ca. 200 BCE-850 CE) (Carswell et al., 2013; Bohingamuwa 2017).

\section{Material and methods}

The present study is based on the observations and analyses of 1689 charcoal remains from these three sites, Kirinda, Kantharodai and Mantai from the different chronological periods excavated (Table 1). The charcoal remains were removed from the flotation samples recovered during the excavation of the three archaeological sites (Murphy et al., 2018; Kingwell-Banham et al., 2018). The study is based on the identification of charcoal from the $4 \mathrm{~mm}$ flotation fraction from different stratigraphic units/contexts as defined by the excavation. The number of studied fragments varied from each site, phase and unit (Table 1) as charcoal samples were based upon availability, viability and preservation conditions. The largest collection of charcoal fragments was from Kirinda. In contrast, the sites of Kantharodai and Mantai had a higher number of excavation units floated but fewer charcoal fragments recovered from each unit. Material from Kirinda came from two different trenches (K03 and K02) that were excavated. The units in each phase examined belong to artificial layers that were sampled for environmental studies (Murphy et al., 2018; Kingwell-Banham et al., 2018).

Charcoal identification was carried out using a metallographic microscope with reflected light and dark and bright fields with x50, x100, x200, ×500 magnifications. Images taken for further observation and confirmation of taxa recording were carried out using a Scanning Electron Microscope (SEM). These facilities were located at the Wolfson Archaeological Science Laboratories at the Institute of Archaeology (UCL). The identification process included a first phase of observations to learn tropical wood anatomy characteristics and record features of the archaeological charcoal, followed by a second phase of classification based upon consulting the UCL comparative collection, the South India Wood Atlas by Asouti and Fuller (2008), and additional sources including: Inside wood (2004 onwards), Ogata et al. (2008). The Wood Atlas by Asouti and Fuller (2008) has a limited number of taxa but includes the most important and clear descriptions of charred remains of South India charcoal. The identification categories included in the present analysis are families (i.e. Fabaceae), genus (i.e. Wrightia) and species (Chloroxylon swietenia), depending on the reliability of features. Other taxa have been classified using standard markers with regards to 
increasing uncertainty, from $\mathrm{cf}$. (i.e. Tectona $\mathrm{cf}$. grandis), type (Acacia type nilotica) or grouping to a pair of genera (i.e. Canthium/Gardenia).

In tropical regions, the most problematic aspects of any anthracology study is the high diversity of woody plants and the limitations surrounding accuracy of identification due to the difficulties in distinguishing species from the same families or genera (Dotte-Sarout, 2011, Dotte-Sarout et al., 2015; Scheel-Ybert, 2002; Hubau et al., 2012; Byrne et al., 2013, Byrne et al., 2020, Dotte-Sarout et al., 2015, Höhn et al., 2018, Höhn and Neumann, 2018). Indeed, diversity in tropical regions is much higher than in temperate or Mediterranean anthracological assemblages in which most assemblages have up to 30 taxa. Therefore, it is important to obtain and study a number of charcoal fragments, approximately 400 charcoal for each unit or context, to achieve a reliable data set for tropical regions (Dotte-Sarout et al., 2015). Quantification is based on the number of remains; however, ubiquity has been also considered to evaluate our results when the minimum number of examined charcoal fragments was not possible. In addition, to understand and compare the examined sites in this study we have considered the relative value of taxa across the entire site assemblages.

To understand the complexity of the vegetal communities that these taxa represent and to overcome the possible limitations that less than $100 \%$ of the remains have been identified we have grouped the taxa results according to their ecological description (Table 2). The ecological zones are designed according to the vegetation in Sri Lanka and the groups set out by Asouti and Fuller (2008); although originally defined for the Indian subcontinent, the ecological zones are not hundred per cent equivalent to those of Sri Lanka, nevertheless they provide a useful approximation for this study. Taxa groupings including a large number of species (e.g. Euphorbiaceae/Apocynaceae) are not included in this table. The vegetal communities are Wet/Moist Evergreen/Deciduous Forests, wet and Intermediate zones, dry deciduous, dry evergreen/dry evergreen scrub, dry savannah, mangrove and river dry (Table 2).

\section{Results}

Most of the identifiable fragments could be identified to family and/or genus. The species category was achieved and used in the monotypic species such as Limonia acidissima and Chloroxylon swietenia (Appendix Supplementary materials). Occasionally, such as in the case of cf. Punica granatum, the species has also been included, as this is the only one in the region. The monocotyledons identified corresponded mainly to palms and the identification has been limited to cf. Cocos nucifera (Appendix Supplementary materials). There are a number of monocotyledons present in Sri Lanka including Pandanaceae, Musaceae, Gramineae and Palmae (Arecaceae) (Ashton et al., 1997). Among the species from the Palmae family the diversity in Sri Lanka is large including several species such as Areca cathechu Borassus flabellifer, Caryota urens, Cocos nucifera, Corypha umbraculifera, Oncosperma fasciculatum, Phoenix farinifera, Phoenix zeylanica, Roystonea regia (Ashton et al., 1997). Anatomy of these monocotyledons is very complex and criteria to distinguish among them are based on the arrangement and shape of the vascular bundles, the type of vessels and their characters (Detienne and Jacquet, 1999; Tomlinson, 2006; Thomas, 2011, 2013; Thomas and De Franceschi, 2013; Schmier et al., 2020(Fathi et al., 2014)(Kuo-Huang et al., 2004)(Parthsarathy and Klotz, 1976). The characters shown in the Appendix Supplementary materials $2 \mathrm{a}, 2 \mathrm{~b}$ and $2 \mathrm{c}$ show dense distribution of oval shaped vascular 
bundles and the presence of 2 vessels that could be similar to various monocotyledon families including Pandanaceae and Palmae (Detienne and Jacquet, 1999; Schmier et al., 2020).

The difficulty of observing the characteristics and complexity of the anatomy of palms means that further research is needed to confirm this species' identification. The presence of Cocos nucifera on or around these sites is highly likely and indicated by the recorded presence of coconut shells in the archaeobotanical record in Kirinda and Kantharodai and echinate spheroids phytoliths produced in palms overall in Mantai (Murphy et al., 2018; KingwellBanham et al., 2018). We, therefore, regard Cocos nucifera as the most probable palm species in these contexts. Differences between the stem and the petiole should also be considered, as the petiole is usually the most suitable part of the plant to be used as fuel as suggested by several authors (Bouchaud et al., 2012; Thomas, 2013). According to our observations the differences regarding the distribution of the fibrous part external to the xylem and the shape of the vascular bundles are not clear enough to suggest that these fragments are part of the petiole or the stem (Appendix Supplementary material 2a). Beyond this identification some aspects should be analysed in depth in the future regarding the identification of these fragments that would most likely correspond to different parts of the plant which are characterize by differences in the characters providing appropriateness for different purposes (Sudo, 1980; Killmann and Fink, 1996; Bouchaud et al., 2012).

Fabaceae is the most recurrent taxon in these assemblages. While some of these fragments can be further differentiated, such as the genera Dalbergia and Pterocarpus, further identification is limited by the lack of certain anatomical features which are not always present and preserved in the examined charcoal remains (Appendix Supplementary materials). The Acacia genus is an extremely large and diverse genus. Several recent efforts have been made to distinguish its numerous types in different regions of the world including charcoal analyses (Demicoli, 2015; Lancelotti, 2018; Mvimi 2019; Byrne et al., 2013, 2020). Parenchyma and ray width are one of the most significant criteria to distinguish amongst its different possible types and these types are most commonly grouped according to the species growing in the area (Demicoli, 2015; Lancelotti, 2018; Mvimi 2019; Byrne et al., 2020). In our assemblages, for the genus Acacia, we have identified and distinguished two types according to ray width (Asouti and Fuller, 2008). Acacia type nilotica for fragments with multi-seriated rays and Acacia type leucophlea with 2-4 seriated rays (Appendix Supplementary materials). It must be noted that the diversity of Acacia spp. in South India and Sri Lanka is high and includes a larger number of species that can be expected to fit within these two types (Asouti and Fuller 2008). For taxa from the Fabaceae family there was less abundance in comparison. Taxa such as Albizia, Cassia or Tamarindus were observed based upon very limited characters. Therefore, based upon the similarity among these species and due to the quality/size of the preserved charcoal fragments identification did not go beyond larger group categories.

For the Rubiaceae family, we have used Canthium/Gardenia to classify charcoal with the same anatomical features that could eventually correspond to several different species (Appendix Supplementary materials). When possible, based on preserved features, another genus, such as Ixora, has been identified (Appendix Supplementary materials).

The degree of the level of identification for each site depended on the preservation and the accuracy of the taxa determination. Between 60 and $68 \%$ of the fragments have been assigned to a taxonomy category; the family being the most recurrent category (Fig. 3). The undetermined charcoal fragments are not a high proportion at Kirinda and Mantai and thus 
correspond to standard values one would expect within archaeological charcoal analyses. Kantharodai shows higher values of undetermined fragments as a consequence of poorer preservation of the charcoal (Fig. 3). In comparison to the other two studied sites there is also relatively low values of identifiable charcoal fragments as the quality of the charcoal fragments does not allow further identification. The category of "cf.", indicating uncertainly due to lack of some anatomical key features is between 3 and 5\% of the total assemblage. There is also a relatively high number of fragments that correspond to new taxa. New taxa are defined as charcoal fragments which have not been identified and classed to a taxon but show different characters that may allow them to be matched to a taxon in the future. These "new taxa' types will probably increase the number of taxa in the assemblage with 4-6 new taxa increasing the overall assemblage's diversity (Fig. 3).

The results from Kantharodai, from all seven phases, reveals 14 families and 19 taxa (Table 3). If we consider the taxa ubiquity, the most significant taxa are Fabaceae, Wrightia, Ziziphus, Canthium/Gardenia and cf. Cocos nucifera. It is interesting to note the results from phase VI in which a single sample had a large quantity of charcoal fragments identified as Rhizophoraceae remains $(\mathrm{N}=83)$, as this taxon is present with only 1 to 3 fragments present in the rest of the phases or samples examined at this site (Table 3).

Kirinda yielded the largest assemblage, in terms of fragment count $(\mathrm{N}=1049)$, and a study of 400 fragments from two phases was possible. Phase 3 from trench KR03 and the samples from trench KR02 yielded fewer fragments. In the assemblage, the most significant taxa was Fabaceae, among which Dalbergia, Acacia and Pterocarpus stand out in all the phases examined (Table 4). The other significant taxon was Canthium/Gardenia with values ca $15 \%$. Several taxa Meliaceae, Moraceae and Wrightia had low present counts but were recurrent across all the phases examined (Table 4).

Mantai yielded a limited number of charcoal fragments with a low quality of charcoal preservation which limited somewhat the identifications (Table 5). The most significant taxon is cf. Cocos nucifera which is present with the highest number of remains in all phases and samples across this site. There are other taxa present such as Rubiaceae, Vitex, Wrightia and very few Fabaceae fragments (Table 5). These results are probably biased due to the low number of fragments present in the recovered assemblage.

Diversity at the examined sites is determined according to the number of charcoal fragments studied for each unit or phase. Phases with a low number of fragments present yielded a reduced number of taxa, whereas phases with a higher number of fragments present yielded a higher number of taxa (Fig. 4a). The type of context and its formation processes likely affected preservation and the diversity for each archaeological unit. In general, units with a number of charcoal fragments between 50 and a 100 showed a diversity between 6 and 12 taxa (Fig. 4b). However, the number of taxa is not always directly correlated with the number of fragments; some units had a large number of fragments with a low diversity of taxa (Fig. 4b). At Kirinda, the number of charcoal fragments examined per phase achieved the minimum number $(n=400)$ in order to be considered robust and reliable. The saturation curve at Kirinda illustrates how the stability of the curve is achieved with 300 fragments. Fig. 5 displays a relatively stable curve with 300 fragments with a slight further increase in diversity beyond 400 fragments. However, the majority (ca. 70\%) of taxa appear before the analyses of 200 fragments is achieved (Fig. 5).

\section{Discussion}




\subsection{Vegetation in Sri Lanka in historical times: arboreal cover and human impact on the landscape}

According to the charcoal obtained data at Kirinda, the most significant vegetal community is formed of dry deciduous forests (Fig. 6, Fig. 7). The composition of these vegetal communities is dominated by Fabaceae among which Dalbergia and Pterocarpus are the dominant trees. Other species such as Meliaceae would also be part of the tree canopy. The presence of Chloroxylon swietenia, Ziziphus or Limonia acidissima suggests the importance of thorny shrubby vegetation which are usually reported as indicators of human disturbance (Perera, 2001; Venkateswaran and Parthasarathy, 2003; Dilhan et al., 2002). There are significant values for dry evergreen scrub represented by Rubiaceae (Canthium/Gardenia) being present. Rubiaceae, represents a wide range of species, among which Canthium/Gardenia, are amongst others evergreen scrub growing as undergrowth in both humid and dry forests (Meher-Homji, 2001; Asouti and Fuller 2008). This group of species might also indicate human disturbance in which open forests allow for the development of scrub species amongst other trees (Mehta et al., 2008). Wet deciduous forest taxa values are low at Kirinda indicating that species from wet ecozones were located further from the settlement but occasionally acquired and used at the site. At Kirinda, the scarcity of cf. Cocos nucifera, is in accordance with the archaeobotanical record (Murphy et al., 2018). However, the phytolith evidence records the presence of palms in most of the environmental samples examined, which might suggest the more routine use of palm leaves for specific purposes (mats, baskets, textiles etc) without exploitation of their stems on the same scale. The specific use of palm for fuel might be connected to fuel choice, e.g. for industrial manufacturing, associated with urban sites such as Mantai.

Finally, the taxa values observed at Kirinda do not show substantial changes in relation to the chronological sequence (Figs. 6 and 7). Hence, we have no evidence for environmental or vegetation cover changes during the analysed period, 600-900 CE. In comparison to urban sites we should consider for Kirinda a fuel exploitation closely linked to agricultural practices and daily live fuel consumption, that would eventually cause modifications on the landscapes but allowed a conservation of the main vegetal communities.

At Kantharodai, the values of dry deciduous forests and the shrubby composition is lower in comparison to Kirinda. This can only be partly attributed to the high numbers of mangrove wood (Rhizophoraceae) from a single sample (Fig. 7). Rhizophoraceae characterizes mangrove forests which might be extended into the marshy zones, located nearby the site of Kantharodai. Mangroves are complex ecosystems which include trees and shrubs that are spread out over saltmarsh areas along the seaside coast (Jayatissa et al., 2002). Resources from Mangrove ecosystems have proven significant for human subsistence in several periods since the Pleistocene as they provide a number of important resources, primary amongst them being wood resources (Erlandson and Braje, 2015) but they also offer many marine resources such as crabs, fish, shell-fish and birds. Probably, in the assemblages under study, there are other species besides Rhizophoraceae among the undetermined categories and we might suggest a higher diversity of ecosystem exploitation. However, the evidence is scarce aside from a single context at Kantharodai that might indicate a specific use. The presence of cf. Cocos nucifera in the Kantharodai charcoal assemblage is also low $(\mathrm{N}=26)$ (Fig. 7) but its frequency in the macro-remains (as endocarp) and phytolith record is high, which would suggest that its wood was less preferred as a fuel at this time (Murphy et al., 2018). 
At Mantai, the most represented groups are palm (cf. Cocos nucifera) and taxa that belong to the vegetal community formed of dry deciduous taxa (Fig. 7). At the inland areas surrounding the outside of the city of Mantai there might be similar vegetal communities as in other parts of the region including dry deciduous forests or open savannah woodlands. However, the importance of palms could be related to their specific use for fuel in certain activities, perhaps associated with industrial activities found in the more urban setting of Mantai. While palm orchards may be suggested by their high presence in the phytolith record (Kingwell-Banham et al., 2018), the higher usage of their wood stands out at Mantai, in comparison to the other two sites examined in this study.

The vegetation record obtained by the anthracological record suggests a diversity of vegetation types. The heterogeneity of the charcoal record includes taxa from different ecozones which may suggest that fuel was a consequence of the use of by-products as forest clearance took place for agriculture. In southern India, during the Iron Age and the Early Historical Period, there was marked agricultural diversification at this time, with an increased number of millet and pulses species, tree cotton cultivation, and in some regions for the first time some irrigation as rice spread south (Cooke and Fuller, 2015, Morrison, 2016; KingwellBanham 2019). But in sum, this can expect to have increased the clearance of forests, which is evident in the limited pollen records and carbon isotope records of peninsular India that span the first millennium BCE and early centuries CE (e.g. Kingwell-Banham and Fuller, 2012; Prasad et al., 2014; Goisan et al., 2017). In Sri Lanka, according to the data obtained from this study, we cannot observe these changes as we lack the robust data from earlier periods and there are no evident changes in the representation of taxa related to the increase of maritime trade or the impact of agriculture. However, different activities regarding agricultural systems, metallurgy, glass beads and ceramic production etc. as well as activities of daily life (light, fuel as heat, food transformation) in urban cities such as Mantai might affect forests in the nearby areas. The diversity of vegetation types present in these assemblages might correspond to the management of different resources as well as a disturbed vegetation as indicated by the prominence of scrub plants.

\subsection{Woody plant uses in Sri Lanka historical times}

Charcoal remains from these three different sites allow for the discussion of several aspects of wood uses. The charcoal remains from Kirinda, Kantharodai and Mantai are related mainly to the use of wood as fuel. Wood was an available resource and would have been the main fuel used for domestic and industrial purposes (Nandasena et al., 2012). However, other fuels, such as cow dung or paddy husk, could have also been used in areas where there was a scarcity of wood availability or wood by-products from certain industrial processes (Solangaarachchi, 2011; Lancelotti, 2018). The main component of these assemblages is firewood that might have been used in domestic households and/or for industrial processes (e.g. glass bead and pottery production). This data set cannot express the full complexity of fuel practices within industrial activities requiring large amount of fuel, however, one can point out several aspects related to wood uses and properties from this assemblage. In urban sites the number of activities requiring fuel usage are numerous and the use of fuel had a 
human input value cost including wood calorific value and its transport back to site. At Mantai production of glass and glass products such as beads and bangles as well as local pottery is enormous (Bohingamuwa, 2017) requiring a huge amount of fuel wood. Daily fuel requirements are related to domestic activities such as lighting, cooking, heating and, industrial and/or technological processes including glass bead or ceramic production, and textile processing amongst others. At Mantai and Kantarodai, the results might indicate mixed charcoal usage from different activities including domestic and industrial fuel use. The recurrent presence of palms and the highest values of palm wood at Mantai may indicate their specific use in urban industrial processes, as it is a multipurpose species for firewood or building material (Searles, 1928; May and Tuckson, 2000; Chan and Elevitch, 2006). Also, it should be considered the possibility of the exploitation of palm petioles, which availability is higher than the stem (Banzon, 1984). However, this interpretation should be taken cautiously requiring further anatomical analyses on the studied assemblage. The lower values of deciduous dry forest species and open savannah species might be related to the distance from the forests to the sites and the increase of disturbed land near the cities. On the other hand, at Kirinda, the main fuel was collected from the deciduous dry forests favouring Fabaceae family species as well as Rubiaceae shrubs and could indicate more local availability of such woods.

Even if there is no clear evidence of the relationship between the presence of these species with their specific contexts and their use, their potential can be evaluated based on known properties. Cloth production is well established through evidence of seed remains such as Gossypium (cotton), which was present at both Kirinda and Kantharodai (Murphy et al., 2018; Tyagi 2006). However, there is little evidence of other technological processes involved in the obtaining of plants or animal textiles and/or hide products requiring the use of wood (Janaway and Coningham, 1995). It is usually the bark of certain plants which provides tannins that can be used in the tanning process (Cardon and Chatenet, 1990). This is especially significant for mangrove taxa (e.g. Rhizophoraceae) that have high concentrations of tannins in the bark that are traditionally used in this process (Baba et al., 2013; Punrattanasin et al., 2013). Also, mangrove wood is very valuable and used to produce charcoal for commercial purposes (Baba et al., 2013; Erlandson and Braje, 2015; Ghosh et al., 2015), however, the limited archaeological data from Kantharodai in which mangrove values are high, does not permit enough evidence to support this hypothesis. Other plant parts, such as leaves and flowers, can also be used as dyes, and in the studied assemblages are represented by Wrightia (W. tinctoria), Morinda tinctoria, Pterocarpus, Rhizophoraceae and Chloroxylon swietenia; all of which have dyeing properties that can be used on textiles (Gokhale et al., 2004; Meena et al., 2007; Das et al., 2020). These taxa are in general, more significant in number at Kantharodai than at Kirinda and Mantai.

The results from the studied sites demonstrated that there were several trees which produced edible fruits including Ziziphus, Ficus, Limonia acidissima, cf. Punica granatum and cf. Cocos nucifera. Food plants in the wild and cultivars are numerous in Sri Lankan flora with some endemic and others that have been introduced during different periods (Fuller et al., 2011). Among the charcoal remains there is no evidence of introduced crop trees/cultivars. Fruit producers could be expected to grow naturally in local environments. Coconuts palms could have been the only tree in these assemblages that could have been cultivated in the cities' orchards (Kingwell-Banham et al., 2018; Murphy et al., 2018). Furthermore, the absence of major fruit woods (Citrus or Mangifera) and species from the humid tropical 
areas, suggests a late incorporation of these cultivars, in contrast to late Chalcolithic and Iron Age finds in India (Kingwell-Banham and Fuller 2012).

Aside from food resources there are a number of tree species in Sri Lanka, overall concentrated in the rainforest, in which a part of the plant provides either medicinal or condiment products (Russell-Smith et al., 2006). However, taxa with known medical uses are few in number, in most charcoal assemblages, indicating most wood remains correspond to fuel use. It is difficult to prove any specific medicinal or consumption use for these purposes in the studied contexts. For example, species such as Strychnos (S. nux-vomica, S. potatorum), which is present at all the studied sites, can be used to extract strychnine which is a highly poisonous material that has been used for different medical/magical purposes (Asouti and Fuller 2008; Bradfield et al., 2015; Guo et al., 2018). This species was part of the dry deciduous forests and is recurrent at Kirinda and Mantai in low numbers which could indicate occasional fuel use.

Many of the woods identified in this study could have uses related to building, ship building or object manufacturing (Gunawardana, 2003). Dalbergia, Pterocarpus, Tectona, Meliaceae, Chloroxylon swietenia, cf. Cocos nucifera all possess high quality timbers for such construction uses. Coconut palm are ubiquitous and traditionally used as a multipurpose plant and could also be used for its fibers, craft objects or building material (Searles, 1928; Gunawardana, 2003). If used as fuel, it is likely that the petiole were the part of the plant which was exploited and used. Sri Lanka was a key strategic point in different trade routes on the Indian Ocean. Trade routes from Africa, the Middle and Near East reveal sea connections that were established during the early historical periods (Warmington, 1928; Charvat, 1993 Muthucumarana et al., 2014; Bopearachchi, 2002; Bohingamuwa, 2017; Carter, 2006; Seland, 2014; Boivin et al., 2017). Also, trade from India to Sri Lanka has been noted and described for the historical periods (Tyagi, 2006; Bopearachchi, 2002). Sri Lanka's geographic position was used as a stopping point between west to east routes as suggested by various lines of evidence for foreign trade including linguistic, genetics and archaeological evidence (Fuller et al., 2011; Erlandson and Braje, 2015; Boivin et al., 2017). Objects (ceramics, glass beads, coins) and plant food evidence (spices, imported grains and fruits) have been identified within the archaeological record supporting long-distance trade. Among the studied sites Mantai and Kantharodai were key enclaves on these trade routes which strengthen Sri Lanka's urbanization progress and increased the complexity and organization needs of its population (Bopearachchi, 2002; Bohingamuwa 2017, 2018, 2019; KingwellBanham et al., 2018; Murphy et al., 2018). Archaeobotanical evidence of trade at Mantai are noted through several imported species including rice, pepper and wheat (Kingwell-Banham et al., 2018). However, the charcoal assemblage does not show any evidence of imported taxa, but instead highlights how wood fuel use was mainly from local sources. The paucity of imported materials at Kirinda reinforces the interpretation of its status as a regional fishing settlement and the fact that it was not involved in major trade exchanges (Murphy et al., 2018).

Evidences of shipwrecks from different periods indicate that naval architecture used a wide range of wood taxa for the various elements in a ship and these were mostly local to the building location (Devendra 1999; Guibal and Pomey, 2003; Burger et al., 2010; Gaur et al., 2011; Devendra and Muthucumarana, 2013). In the combined charcoal assemblage quality timber species, specially taxa such as Dalbergia, Tectona and Pterocarpus, were probably used for building or ship manufacturing and repair (Tripati et al., 2005; Burger et al., 2010). Also, palms could be used for naval architecture providing raw material for several ship 
elements (Vosmer et al., 2003; Gunawardana, 2003). Based upon the anthracological evidence in this study there is no evidence of imported woods from any of the three sites, but we cannot rule out that these sites could have been a source of exported timber for ship manufacturing or repairing.

\section{Conclusion}

In summary, the taxa assemblage identified from the three examined sites is characterized by local vegetal communities. This sometimes included coastal taxa (mangroves and palms), taxa of open agricultural lands (palms) and some dry deciduous and dry scrub taxa. There is no evidence for major chronological changes over time but instead there is evidence for local sourcing of wood fuels in human impacted environments, woodlands near the sites. The urban centre of Mantai may have included more targeted use of palm wood for certain purposes and hence distinguishing the charcoal record of this urban port site from the other two sites examined. There are a wide range of potential uses of the identified taxa, in tanning and dying, constructing and ship-building and a identified few taxa were sources of edible fruits. Nevertheless, domestic fuel use, from local wood collection, appears to be the main component of the anthracological record at Mantai, Kantharodai and Kirinda, representing three different points around the Sri Lankan coastline.

This study is significant in methodological terms, as it represents the first large scale anthracological study from flotation samples from Sri Lanka. This study highlights the high potential to recover identifiable charcoal in significant quantities through systematic flotation. Despite the study's tropical location of Sri Lanka, the high diversity of its woody flora, limitations of existing reference collections, limited existing sources on identification for South India, Sri Lanka, and other online resources, we have still demonstrated that it is possible to achieve reasonable levels of taxonomic resolution for the majority of charcoal remains. Therefore, anthracological analyses represents a branch of archaeological science with a high potential to contribute to reconstructing long-term human-environment interactions in Sri Lanka as more sites are sampled.

\section{Declaration of competing interest}

The authors declare that they have no known competing financial interests or personal relationships that could have appeared to influence the work reported in this paper.

\section{Acknowledgments}

This research was funded by the Spanish Government Salvador de Madariaga Ministerio de Educación, Cultura y Deporte (2018PRX17/00308). Research by E. Allué is funded by the Spanish government research projects MICINN-FEDER PGC 2018-093925-B-C32, MICINN (PID 2019-103987 GB-C31), the Generalitat de Catalunya research project 2017 SGR 836 
andsupported by the Spanish Ministry of Science and Innovation through the "María de Maeztu" excellence accreditation (CEX 2019-000945-M). The research was carried out at the Institute of Archaeology (UCL) where a number of people provided E. Allué with support that we would like to thank including the UCL Archaeobotany Work Group and Lab students, Dr Michèle Wollstonecroft (UCL) and Dr Tom Gregory (UCL). We would also like to thank P. Gasson (Kew Gardens) who allowed for the consultation of the wood anatomy comparative collection.

Archaeological fieldwork at Kantharodai and Kirinda was undertaken as part of the Sealinks Project, funded by a European Research Council award (grant no. 206148) to NLB. Mantai radiocarbon dating was funded by a Natural Environmental Research Council (NERC) Radiocarbon Facility grant to NB (NRCF project no. 2010/1/3). Our thanks to Dr Sheng Xu for his work extracting dates from difficult materials. Archaeobotanical analyses on macroremains (CM, DQF) was supported by the ComPAg project, funded by an ERC advanced grant (grant no. 323842), while studies at Mantai, all phytolith analyses and additional radiocarbon dating of rice was supported by the Early Rice Project (EKB, DQF), with grants from the UK Natural Environment Research Council (NE/K003402/1790 and NE/N010957/1). Support for Wierathne Bohingamuwa was provided by the Oxford University Clarendon Fund, St Cross College and Institute of Archaeology travel grants. Thanks to field staff and colleagues who assisted with these excavations and environmental collections in Sri Lanka. In particular, the excavations at Kantharodai were led by Dr. Nimal Perera, former Deputy Director General of Excavations, Department of Archaeology, Sri Lanka. Director-General of the Central Cultural Fund Professor Gamini Adikari was one of the co-directors of the SEALINKS Sri Lanka Project and was involved in obtaining permissions and assisting Wijerathne Bohingamuwa and colleagues including Mr. T.D.C. Pushpakumara, Mr. Susantha Nihal, Mr. G. Jeyatheeswaran in environmental sampling undertaken at Kantharodai.

Thanks to Patrick Austin for his assistance in the Archaeobotanical Laboratory at UCL for sorting archaeobotanical samples from Kantharodai. Thanks to Melissa Tan for processing the phytoliths from both Kirinda and Kantharodai at UCL. Thanks to Honorary Research Assistant Amanda Leon, Institute of Archaeology, UCL for editing and commenting upon the final draft of the manuscript. Kirinda was undertaken as a collaborative project involving a number of Sri Lankan and British institutions. Professor Adikari Gamini was a main project partner, and we acknowledge the support of the Central Cultural Fund in terms of funding as well as provision of staff and logistical support. We also gratefully acknowledge the assistance received from Mr. R.M. Rathnayake, Project Manager, Tissamaharama, during our work at Kirinda. A special thanks is due to Ms. Kaushalya Gunasena, CCF co-ordinator for SEALINKS Southern Sri Lankan Ports Project for all her hard work coordinating all parties involved. We would like to thank all Sri Lankan fieldstaff and students who participated in excavations at the site and Hettie Horton who headed up the flotation at Kirinda. We would also like to acknowledge both Dr S.U. Deraniyagala and Dr S. Dissanayake, former and present Director Generals of the Department of Archaeology, Prof. Gamini Adikari and Prof. Jagath Weerasinghe, Former Director of CCF and PGIAR, and Prof. Gamini Senanayake, Vice Chancellor, University of Ruhuna for granting permission and facilitating our project. We would like to thank the E. Asouti editor of the Special Volume Charcoal Science in 
Archaeology and Palaeoecology, and the two anonymous reviewers that helped improving our manuscript.

\section{References}

Adikari, G., 2009. Food and People: Animal Remains from Excavation in the Kirindi Oya Basin (1000 BCE-1400 CE). PhD thesis. Postgraduate Institute of Archaeology. University of Kelaniya, Sri Lanka.

Asouti, E., Fuller, D. Q. 2008. Trees and woodlands of South India: Archaeological perspectives. Left Coast Press.

Asouti, $\quad$ E. 2019. 7th International Anthracology Meeting, Abstracts, Sep 2019, Liverpool, United Kingdom

Baba, S., Chan, H. T., Aksornkoae, S. 2013. Useful products from mangrove and other coastal plants. International Society for Mangrove Ecosystems.

Badal, E., Carrión, Y., Macías, M., Ntinou, M. (Eds.) 2012. Wood and charcoal. Evidence for human and natural history. Sagvntvm Extra-13.

Banzon, J. A. (1984). Harvestable energy from the coconut palm. Energy in Agriculture, 3, 337-344.

Bodin, S. C., Scheel-Ybert, R., Beauchêne, J., Molino, J. F., Bremond, L. 2019. CharKey: An electronic identification key for wood charcoals of French Guiana. IAWA journal, 40(1), 75S20.

Bohingamuwa, W. 2017. Sri Lanka and the Indian Ocean contacts: internal networks and external connections. $\mathrm{PhD}$ dissertation, University of Oxford.

Bohingamuwa, W. 2018. Ancient Mahatittha (Mantai) in Sri Lanka: A historical biography, The Journal of the Royal Asiatic Society of Sri Lanka, Vol. 62, Part II, pp-23-50.

Bohingamuwa, W. 2019. The Galle Fort World Heritage Site: A Nature-Culture Approach to the Conservation of Cultural Heritage along the Southern Coast of Sri Lanka. Journal of World Heritage Studies, special issue, 29-37

Boivin, N., Crassard, R., Petraglia, M. (Eds.). 2017. Human dispersal and species movement: from prehistory to the present. Cambridge University Press.

Bopearachchi, O. 2002. Archaeological evidence on shipping communities of Sri Lanka. Ships and the Development of Maritime Technology in the Indian Ocean, 92-127.

Bouchaud, C., Thomas, R., Tengberg, M. (2012). Optimal use of the date palm (Phoenix dactylifera L.) during Antiquity anatomical identification of plant remains from Madâ in Sâlih 
(Saudi Arabia) Saguntum: Papeles del Laboratorio de Arqueología de Valencia, No Extra 13, pp. $173-186$

Bradfield, J., Lombard, M., Wadley, L. 2015. Southern African arrow poison recipes, their ingredients and implications for Stone Age archaeology. Southern African Humanities, 27(1), 29-64.

Burger, P., Charrié-Duhaut, A., Connan, J., Albrecht, P., Flecker, M. 2010. The 9th-CenturyAD Belitung Wreck, Indonesia: analysis of a resin lump. International Journal of Nautical Archaeology, 39(2), 383-386.

Byrne, C., Dotte-Sarout, E., \& Winton, V. (2013). Charcoals as indicators of ancient tree and fuel strategies: An application of anthracology in the Australian Midwest. Australian Archaeology, 77, 94-106.

Byrne, C., Dooley, T., Manne, T., Paterson, A., Dotte-Sarout, E. (2020). Island survival: The anthracological and archaeofaunal evidence for colonial-era events on Barrow Island, northwest Australia. Archaeology in Oceania, 55(1), 15-32.

Cardon, D., Chatenet, G. D. 1990. Guide des teintures naturelles: plantes, lichens, champignons, mollusques et insectes. Delancahux et Niestlé ed. Paris.

Carswell, J., Deraniyagala, S., Graham, A. 2013. Mantai: city by the sea. Lindensoft-Verlag.

Carter, R. 2006. Boat remains and maritime trade in the Persian Gulf during the sixth and fifth millennia BC. Antiquity, 80(307), 52-63.

Charvat, P. 1993. External Contacts of Sri Lanka in the 1st Millennium AD (Archaeological evidence from Mantai). Archív orientální, 61, 13-29.

Coningham, R., Strickland, K., 2008. Sri Lanka. Encyclopedia of Archaeology 791-795.

Damblon, F. (Ed.) 2013. Proceedings of the Fourth International Meefing of Anthracology: Brussels, 8, 13th September 2008, Royal Belgian Institute of Natural Sciences. BAR International Series 2486, Oxford Archaeo Press

Das, A. K., Islam, M. N., Faruk, M. O., Ashaduzzaman, M., Dungani, R., Rosamah, E., Hartati, S., Rumidatul, A. 2020. Hardwood Tannin: Sources, Utilizations, and Prospects. In: Aires, A. (Ed.) Tannins-Structural Properties, Biological Properties and Current Knowledge. IntechOpen.

Demicoli, M. 2015. Diachronic Study of Anthracological remains from the South Indian Site of Sannarachamma. Ms Thesis in Environmental Archaeology of University College London.

Deraniyagala, S.U. 1992. The Prehistory of Sri Lanka: an Ecological Perspective. Sri Lanka. Parts 1 and II. Purvidy Deprtamntuva. Dept. of Archaeological Survey, Govt. of Sri Lanka, Colombo. 
Deraniyagala, S.U. 2004. Pre-Historic Basis for the Rise of Civilization in Sri Lanka and Southern India: Second Vesak Commemoration Lecture. Sri Lanka Deputy High Commission, Chennai.

Detienne, P., Jacquet, P. 1999. Manuel d'identification des bois de Polynésie. Cirad.

Devendra, S. 1999. Archaeology under Sri Lankan waters. Journal of the Royal Asiatic Society of Sri Lanka, 44, 49-71.

Devendra, S., Muthucumarana, R. 2013. Maritime Archaeology and Sri Lanka: globalization, immigration, and transformation in the underwater archaeological record. Historical Archaeology, 47(1), 50-65.

Dilhan, M. A. A. B., Yakandawala, D., Gunatilleke, C. V. S., Bambaradeniya, C. N. B. 2002. Structure and composition of a scrubland vegetation in the lower Walawe basin irrigation extension area in Sri Lanka. Ceylon Journal of Science (Biological Science), 30, 125-145.

Dotte-Sarout, E. 2010. "The ancestor wood": trees, forests and precolonial kanak settlement on New Caledonia Grande Terre: case study and anthracological approach in the Tiwaka Valley (Northeastern Grande Terre). PhD Dissertation. Université Paris I.

Dotte-Sarout, E. 2011. Evaluating methods and results for the application of anthracology to high diversity and high endemism environments: Case study in the Tiwaka Valley, northeastern Grande Terre of New Caledonia. SAGVNtVM Extra, 11, 41-42.

Dotte-Sarout, E. 2017. Evidence of forest management and arboriculture from wood charcoal data: an anthracological case study from two New Caledonia Kanak pre-colonial sites. Vegetation History and Archaeobotany, 26(2), 195-211.

Dotte-Sarout, E., Ouetcho, J., Bolé, J., Barret, D., Sand, C. 2013. Of charcoals and forests: Results and perspectives from an archaeobotanical investigation of precolonial kanak settlement sites in New Caledonia. Pacific archaeology: Documenting the past, 50, 120-137.

Dotte-Sarout, E., Carah, X., Byrne, C. 2015. Not just carbon: assessment and prospects for the application of anthracology in O ceania. Archaeology in Oceania, 50(1), 1-22.

Dotte-Sarout, E., Kahn, J.G. 2017. Ancient woodlands of Polynesia: a pilot anthracological study on Maupiti Island, French Polynesia. Quaternary International, 457, 6-28.

Eichhorn, B., Neumann, K. 2016. Holocene vegetation change and land use at Ounjougou, Mali. In Archaeology of African plant use (pp. 83-96). Routledge.

Ekblom, A., Eichhorn, B., Sinclair, P., Badenhorst, S., Berger, A. 2014. Land use history and resource utilisation from ad. 400 to the present, at Chibuene, southern Mozambique. Vegetation history and archaeobotany, 23(1), 15-32.

Elevitch, C. 2006. Species profiles for Pacific island agroforestry. Cocos nucifera (palm family). April version 2.1. www.traditionaltree.org. 
Erdelen, W. (1988). Forest ecosystems and nature conservation in Sri Lanka. Biological Conservation, 43(2), 115-135.

Erlandson J.M., Braje T.J. 2015. Coasting out of Africa: The potential of mangrove forests and marine habitats to facilitate human coastal expansion via the southern dispersal Route. Quaternary International, 382, 31-41.

Fathi, L., Frühwald, A., Koch, G. 2014. Distribution of lignin in vascular bundles of coconut wood (Cocos nucifera) by cellular UV-spectroscopy and relationship between lignification and tensile strength in single vascular bundles. Holzforschung, 68(8), 915-925.

Fiorentino, G., Magri, D. (Eds.). 2008. Charcoals from the Past: Cultural and Palaeoenvironmental Implications: Proceedings of the Third International Meeting of Anthracology, Cavallino, Lecce (Italy), June 28th-July 1st 2004 (Vol. 1807). British Archaeological Reports Limited.

Franke, G., Höhn, A., Schmidt, A., Ozainne, S., Breunig, P., Neumann, K., 2020. Pits, pots and plants at Pangwari - Deciphering the nature of a Nok Culture site. Azania Archaeological Research Africa, 55, 129-188.

Fuller, D.Q. 2002. Fifty years of archaeobotanical studies in India: laying a solid foundation. Indian archaeology in retrospect, 3, 247-363.

Fuller, D.Q. 2008. Domestication, diffusion and the development of agricultural villages: a study of the South Indian Neolithic. Egbert Forsten.

Fuller, D.Q., Harvey, E.L. 2006. The archaeobotany of Indian pulses: identification, processing and evidence for cultivation. Environmental archaeology, 11(2), 219-246.

Fuller, D.Q., Murphy, C. 2014. Overlooked but not forgotten: India as a center for agricultural domestication. General Anthropology, 21(2), 1-8.

Fuller, D.Q., Murphy, C. 2018. The origins and early dispersal of horsegram (Macrotyloma uniflorum), a major crop of ancient India. Genetic resources and crop evolution, 65(1), 285305.

Fuller, D.Q, Korisettar, R., Venkatasubbaiah, P.C., Jones, M.K. 2004. Early plant domestications in southern India: some preliminary archaeobotanical results. Vegetation History and Archaeobotany, 13(2), 115-129.

Fuller, D.Q., Boivin, N., Korisettar, R. 2007. Dating the Neolithic of South India: new radiometric evidence for key economic, social and ritual transformations. Antiquity, 81(313), 755-778.

Fuller D.Q., Boivin, N., Hoogervorst, T., Allaby, R. 2011. Across the Indian Ocean: the prehistoric movement of plants and animals. Antiquity 85 (328), 544-558.

Gaur, A. S., Muthucumaran, R., Chandraratne, W. M., Orillandeda, B. C., Manders, M., Karunarathna, S., Karunarathna, S, Weerasinghe, P., Dayananda, AMA., Zainab, T., 
Sudaryadi, A., Ghani, KABA., Wahjudin, J., Samaraweera, N. 2011. Preliminary assessment of an early historic (2000-year-old) shipwreck at Godawaya, Sri Lanka. Journal of the Australasian Institute for Maritime Archaeology, 35, 9.

Ghosh, A., Schmidt, S., Fickert, T., Nüsser, M. 2015. The Indian Sundarban mangrove forests: history, utilization, conservation strategies and local perception. Diversity, 7(2), 149-169.

Goisan, L., Ponton, C., Usman, M., Blusztajn, J., Fuller, D., Galy, V., Haghipour, N., Johnson, J.E., McIntyre, C., Wacker, L., Eglinton, T. 2017. Short Communication: Massive Erosion in Monsoonal Central India Linked to Late Holocene Landcover Degradation, Earth Surface Dynamics 5,781-789.

Gokhale, S. B., Tatiya, A.U., Bakliwal, S.R., Fursule, R.A. 2004. Natural dye yielding plants, $3(4), 228-234$.

Guibal, F., Pomey, P. 2003. Timber supply and ancient naval architecture. In: Beltrane, C. (Ed.). Boats, Ships and Shipyards: Proceedings of the Ninth International Symposium on Boat and Ship Archaeology, Venice 2000. Oxbow Books Limited, pp. 35-41.

Gunawardana, R. 2003. Seaways to Sielediba. In: Bandaranayake, S., Dewaraja, L., Silva, R., Wimalaratne, KDG (Eds.), Sri Lanka and the Silk Road of the Sea, second ed. Sri Lanka Institute of International Relations, Colombo, pp. 17-35.

Guo, R., Wang, T., Zhou, G., Xu, M., Yu, X., Zhang, X., Feng Sui, F., Li, C., Tang, L.Wang, Z. 2018. Botany, phytochemistry, pharmacology and toxicity of Strychnos nux-vomica L.: a review. The American journal of Chinese medicine, 46(01), 1-23.

Hather, J.G. 1994. The identification of charred root and tuber crops from archaeological sites in the Pacific. In: Hather, J.G. (Ed.) Tropical archaeobotany: Applications and new developments, pp. 51-64.

Higham, C. F. (1996). A review of archaeology in Mainland Southeast Asia. Journal of Archaeological Research, 4(1), 3-49.

Höhn, A. (2007). Where did all the trees go? In: Cappers R (ed) Fields of change. Progress in African archaeobotany. Barkhuis Publishing, Eelde, Groningen, pp 35-42

Höhn, A. 2018. Plants and People in the African Past: Themes and Objectives of Archaeobotany. Plants and People in the African Past: Progress in African Archaeobotany, 1.

Höhn A. K. Neumann 2017. Charcoal identification in a species-rich environment: The example of Dibamba, Cameroon. IAWA journal / International Association of Wood Anatomists 39(1):87-113.

Höhn, A., Neumann, K. 2018. Charcoal identification in a species-rich environment: The example of Dibamba, Cameroon. IAWA Journal, 39(1), 87-S47.

Höhn, A., Franke, G., Schmidt, A. 2018. Pits at Pangwari: Charcoal taphonomy at a multiphased Nok Site, central Nigeria. In Plants and People in the African Past (pp. 271-299). Springer, Cham. 
Hubau, W., Van den Bulcke, J., Kitin, P., Mees, F., Van Acker, J., Beeckman, H. 2012. Charcoal identification in species-rich biomes: A protocol for Central Africa optimised for the Mayumbe forest. Review of Palaeobotany and Palynology, 171, 164-178.

InsideWood. 2004-onwards. Published on the Internet. http://insidewood.lib.ncsu.edu/search [used during 2018-2019].

Janaway, R.C., Coningham, R.A.E. 1995. A review of archaeological textile evidence from South Asia. South Asian Studies, 11(1), 157-174.

Jayatissa, L.P., Dahdouh-Guebas, F., Koedam, N. 2002. A review of the floral composition and distribution of mangroves in Sri Lanka. Botanical Journal of the Linnean Society, 138(1), 2943.

Kajale, M.D. 1989. Archaeobotanical investigation on megalithic Bhagimohari, and its significance for ancient Indian agricultural system. Man and Environment, 13(2), 87-100.

Kajale, M.D. 1990. Ancient plant economy from excavations at Mantai, district Mannar, northwest Sri Lanka. Ancient Ceylon, 12, 263-6.

Kajale, M.D. 1991. Current status of Indian palaeoethnobotany: introduced and indigenous food plants with a discussion of the historical and evolutionary development of Indian agriculture and agricultural systems in general. New Light on Early Farming. Edinburgh University Press, Edinburgh, 155-189.

Kajale, M.D. 1994. Archaeobotanical investigations on a multicultural site at Adam, Maharashtra, with special reference to the development of tropical agriculture in arts of India. In: Hather, J.G. (Ed.) Tropical archaeobotany: Applications and new developments, pp. 34-50.

Killmann, W., Fink D. 1996. Coconut Palm Stem Processing Technical Handbook. Dept. Furniture and Wooden Products Deutsche Gesellschaft für Technische Zusammenarbeit (GTZ) GmbH. http://www.fao.org/3/ag335e/AG335E00.htm\#TOC.

King, F., Dotte-Sarout, E. 2019. Wood charcoal analysis in tropical rainforest: a pilot study identifying firewood used at toxic nut processing sites in northeast Queensland, Australia. Vegetation history and archaeobotany, 28(2), 163-185.

Kingwell-Banham, E. 2019. Dry, rainfed or irrigated? Reevaluating the role and development of rice agriculture in Iron Age-Early Historic South India using archaeobotanical approaches. Archaeological and Anthropological Sciences, 11(12), 6485-6500.

Kingwell-Banham, E., Fuller, D.Q. 2012. Shifting cultivators in South Asia: Expansion, marginalisation and specialisation over the Long-Term. Quaternary International 249, 84-95

Kingwell-Banham, E., Bohingamuwa, W., Perera, N., Adikari, G., Crowther, A., Fuller, D.Q., Boivin, N. 2018. Spice and rice: pepper, cloves and everyday cereal foods at the ancient port of Mantai, Sri Lanka. Antiquity, 92(366), 1552-1570.

Kuo-Huang, L. L., Huang, Y. S., Chen, S. S., Huang, Y.R. 2004. Growth stresses and related anatomical characteristics in coconut palm trees. IAWA Journal, 25(3), 297-310. 
Lancelotti, C. (2018). 'Not all that burns is wood'. A social perspective on fuel exploitation and use during the Indus urban period (2600-1900 BC). PloS one, 13(3).

Ludemann, T., Nelle O. 2017a. Anthracology: local to global significance of charcoal science. Part I. Quaternary International, 457, 1-5.

Ludemann, T., Nelle O. (2017b) Anthracology: local to global significance of charcoal science Part II. Quaternary International, 458, 1-232

Ludemann, T., Nelle O. 2018. Anthracology: local to global significance of charcoal science. Part III. Quaternary International, 463, 219-424

May, P., Tuckson, M. 2000. The Traditional Pottery of Papua New Guinea. University of Hawaii Press.

Meena, P., Choudhary, S., Nehra, S. 2007. Tannin and Dyes from Plants. Nehra, S. (Ed.). Economic Botany. Pointer publishers, pp. 106.

Mehta, V. K., Sullivan, P. J., Walter, M. T., Krishnaswamy, J., DeGloria, S.D. 2008. Ecosystem impacts of disturbance in a dry tropical forest in southern India. Ecohydrology:Ecosystems, Land and Water Process Interactions, Ecohydrogeomorphology, 1(2), 149-160.

Mercader, J., Panger, M., Boesch, C. 2002. Excavation of a chimpanzee stone tool site in the African rainforest. Science, 296(5572), 1452-1455.

Morrison, K.D., 2016. From Millets to Rice (and Back Again?): Cuisine, Cultivation, and Health in Southern India. In: Walimbe, S.R., Schug, G.R. (Eds.), A Companion to South Asia in the Past. Wiley Blackwell, New York, Chapter 24, pp. 358-373

Murphy, C., Fuller, D.Q. 2017. Seed coat thinning during horsegram (Macrotyloma uniflorum) domestication documented through synchrotron tomography of archaeological seeds. Scientific reports, 7(1), 1-9.

Murphy, C., Weisskopf, A., Bohingamuwa, W., Adikari, G., Perera, N., Blinkhorn, J., Horton, M., Fuller, D.Q. Boivin, N. 2018. Early agriculture in Sri Lanka: New Archaeobotanical analyses and radiocarbon dates from the early historic sites of Kirinda and Kantharodai (Kandarodai). Archaeological Research in Asia, 16, 88-102.

Muthucumarana, R., Gaur, A. S., Chandraratne, W. M., Manders, M., Rao, B. R., Bhushan, R., Khedekar, V.D., Dayananda, A.M.A. 2014. An early historic assemblage offshore of Godawaya, Sri Lanka: evidence for early regional seafaring in South Asia. Journal of Maritime Archaeology, 9(1), 41-58.

Mvimi, M. 2019. Reconstruction of environments and plant use in Holocene Southern Africa: study of macrobotanical remains from Late Stone Age sites of Toteng (Botswana), Leopard Cave and Geduld (Namibia). PhD doctoral dissertation, Muséum national d'histoire naturelle, Paris. 
Nandasena, S., Wickremasinghe, A. R., Sathiakumar, N. 2012. Biomass fuel use for cooking in Sri Lanka: analysis of data from national demographic health surveys. American journal of industrial medicine, 55(12), 1122-1128.

Neumann, K. 1992. The contribution of anthracology to the study of the late Quaternary vegetation history of the Mediterranean region and Africa. Bulletin de la Société Botanique de France. Actualités Botaniques, 139(2-4), 421-440.

Neumann, K., Bostoen, K., Höhn, A., Kahlheber, S., Ngomanda, A., Tchiengué, B. 2012. First farmers in the Central African rainforest: A view from southern Cameroon. Quaternary International, 249, 53-62.

Ogata, K., Fufii,T., Abe,H., Baas, P. 2008. Identification of the timbers of Southeast Asia and the Western Pacific. Kaiseisha press.

Parthsarathy, M. V., Klotz, L. H. 1976. Palm “wood” I. Anatomical aspects. Wood Science and Technology, 10(3), 215-229.

Pearsall, D.M. 2019. Conclusion: Investigating Ancient Lifeways Through Paleoethnobotany. In: Pearsall, D.M. (Ed.). Case Studies in Paleoethnobotany: Understanding Ancient Lifeways Through the Study of Phytoliths, Starch, Macroremains, and Pollen. Routledge, pp. 228-236.

Perera, N.P. 1975. A physiognomic vegetation map of Sri Lanka (Ceylon). Journal of Biogeography, 2 (3), 185-203.

Perera, G.A.D. 2001. The secondary forest situation in Sri Lanka: a review. Journal of Tropical Forest Science, 13(4), 768-785.

Perera, N., Kourampas, N., Simpson, I. A., Deraniyagala, S. U., Bulbeck, D., Kamminga, J., Perera, J., Fuller, D.Q., Szabo, K., Oliveira, N.V. 2011. People of the ancient rainforest: Late Pleistocene foragers at the Batadomba-lena rockshelter, Sri Lanka. Journal of human evolution, 61(3), 254-269.

Perera, A. 2012. Present status of dry-zone flora in Sri Lanka. The National Red List, 165-174.

Prasad, S., Anoop, A. Riedel, N. Sarkar, S. Menzel, P., Basavaiah, N., Krishnan, R. Fuller, D.Q. Plessen, B. Gaye, B. Röhl, U. Wilkes, H. Sachse, D. Sawant, R. Wiesner, M.G. Stebich M. 2014. Prolonged monsoon droughts and links to Indo-Pacific warm pool: A Holocene record from Lonar Lake, central India. Earth and Planetary Science Letters 391,171-182.

Premathilake, R., 2006. Relationship of environmental changes in Central Sri Lanka to possible prehistoric land-use and climate changes. Palaeogeography, Palaeoecology, Palaeoclimatology, 24 (3-4), 468-496.

Premathilake, R., Epitawatta, S., Nilsson, S., 1999. Pollen morphology of some selected plant species from Horton Plains, Sri Lanka. Grana 38 (5), 289-295.

Premathilake, R., Seneviratne, S., 2015. Cultural implication based on pollen from the ancient mortuary complex in Sri Lanka. Journal of Archaeological Science 53, 559-569. 
Punrattanasin, N., Nakpathom, M., Somboon, B., Narumol, N., Rungruangkitkrai, N., Mongkholrattanasit, R. 2013. Silk fabric dyeing with natural dye from mangrove bark (Rhizophora apiculata Blume) extract. Industrial Crops and Products, 49, 122-129.

Roberts, P., Boivin, N., Petraglia, M. 2015. The Sri Lankan 'microlithic'tradition c. 38,000 to 3,000 years ago: tropical technologies and adaptations of Homo sapiens at the southern edge of Asia. Journal of World Prehistory, 28(2), 69-112.

Roberts, P., Boivin, N., Petraglia, M., Masser, P., Meece, S., Weisskopf, A., Silva, F., Korisettar, R., Fuller, D.Q. 2016. Local diversity in settlement, demography and subsistence across the southern Indian Neolithic-Iron Age transition: site growth and abandonment at Sanganakallu-Kupgal. Archaeological and Anthropological Sciences, 8(3), 575-599.

Roberts, P., Perera, N., Wedage, O., Deraniyagala, S., Perera, J., Eregama, S., Petraglia, M.D., Lee-Thorp, J. A. 2017. Fruits of the forest: Human stable isotope ecology and rainforest adaptations in Late Pleistocene and Holocene ( 236 to $3 \mathrm{ka})$ Sri Lanka. Journal of human evolution, 106, 102-118.

Roberts, P., Gillingwater, T. H., Lahr, M. M., Lee-Thorp, J., MacCallum, M., Petraglia, M., Wedage, O, Heenbanda, U., Wainnya-Laeto, U. 2018. Historical tropical forest reliance amongst the Wanniyalaeto (Vedda) of Sri Lanka: an isotopic perspective. Human Ecology, $46(3), 435-444$.

Russell-Smith, J., Karunaratne, N. S., Mahindapala, R. 2006. Rapid inventory of wild medicinal plant populations in Sri Lanka. Biological conservation, 132(1), 22-32.

Scheel-Ybert, R. 2000. Vegetation stability in the Southeastern Brazilian coastal area from 5500 to $140014 \mathrm{C}$ yr BP deduced from charcoal analysis. Review of Palaeobotany and Palynology, 110(1-2), 111-138.

Scheel-Ybert, R. 2002. Evaluation of sample reliability in extant and fossil assemblages. In: Thiébault, S. (Ed.). Charcoal analysis: methodological approaches, palaeoecological results and wood uses: proceedings of the Second International Meeting of Anthracology. Bar International Series, 1063, pp. 9-16.

Scheel-Ybert, R., Beauclair, M., Buarque, A. 2014. The forest people: landscape and firewood use in the Araruama region, southeastern Brazil, during the late Holocene. Vegetation History and Archaeobotany, 23(2), 97-111.

Schmier, S., Hosoda, N., Speck, T. 2020. Hierarchical structure of the Cocos nucifera (Coconut) endocarp: functional morphology and its influence on fracture toughness. Molecules, 25(1), 223.

Searles, P.J. 1928. The most Valuable Tree in the World. The Scientific Monthly, Vol. 27, No. 3 (Sep., 1928), pp. 271-280

Seland, E.H. 2014. Archaeology of trade in the western Indian Ocean, 300 BC-AD 700. Journal of Archaeological Research, 22(4), 367-402. 
Siriweera, W. I. 2002. History of Sri Lanka: from earliest times up to the sixteenth century. Dayavamsa Jayakodi Saha Samagama.

Solangaarachchi, R. 2011. Ancient Iron Smelting Technology and the Settlement Pattern in the Kiri Oya Basin in the Dry Zone of Sri Lanka. PhD dissertation, University of Florida.

Stahl, A. B. 2004. Political economic mosaics: archaeology of the last two millennia in tropical sub-Saharan Africa. Annual Revue of Anthropology, 33, 145-172.

Sudo, S. 1980. Some anatomical properties and density of the stem of coconut palm (Cocos nucifera), with consideration for pulp quality. IAWA Journal, 1(4), 161-171.

Thiébault, S. 2002. Charcoal analysis: methodological approaches, palaeoecological results and wood uses: proceedings of the Second International Meeting of Anthracology, Paris, September 2000 (Vol. 1063). British Archaeological Reports Limited.

Thomas. R. 2011. Anatomie comparée des palmiers - Identification assistée par ordinateur, applications en paléobotanique et en archéobotanique. $\mathrm{PhD}$ Thesis. Botanique. Museum national d'histoire naturelle - MNHN PARIS.

Thomas, R. 2013. Anatomy of the endemic palms of the Near and Middle East: archaeobotanical perspectives. Revue d'ethnoécologie 4, 1-15.

Thomas, R., De Franceschi, D. 2013. Palm stem anatomy and computer-aided identification: The Coryphoideae (Arecaceae). American Journal of Botany 100(2), 289-313.

Thompson, G.B. 1994. Wood charcoals from tropical sites: a contribution to methodology and interpretation. In: Hather, J.G. (Ed.) Tropical archaeobotany: Applications and new developments, pp. 9-29.

Tomlinson, P. B. (2006). The uniqueness of palms. Botanical Journal of the Linnean Society, 151(1), 5-14.

Tripati, S., Sujatha, M., Rao, R.V., Rao, K.S. 2005. Use of timber in shipbuilding industry: Identification and analysis of timber from shipwrecks off Goa coast, India. Current Science, 1022-1027.

Tyagi, M. 2006. Commercial relations between north-India and_Sri Lanka in ancient period: a study. Proceedings of the Indian History Congress. 67, 106-117.

Venkateswaran, R., Parthasarathy, N. 2003. Tropical dry evergreen forests on the Coromandel coast of India: structure, composition and human disturbance. Ecotropica, 9(1-2), 45-58.

Vernet, J.-L. (Ed.) 1992. Les charbons de bois, les anciens écosystèmes et le rôle de l'homme. Bulletin de la Société Botanique de France, 139, 2-4, Société Botanique de France, Paris.

Vosmer, T., Potts, D. T., Naboodah, H. A., Hellyer, P. 2003. The naval architecture of early Bronze Age reed-built boats of the Arabian Sea. In: Potts, D.T., Al Naboodah, H., Nābūdah, H.M., Hellyer, P. (Eds.). Archaeology of the United Arab Emirates. Proceedings of the First International Conference on the Archaeology of the UAE. Trident press, pp. 152-7. 
Warmington, E.H. 1928. The commerce between the Roman Empire and India. Cambridge: Cambridge University Press.

Weisskopf, A., Harvey, E., Kingwell-Banham, E., Kajale, M., Mohanty, R., Fuller, D.Q. 2014. Archaeobotanical implications of phytolith assemblages from cultivated rice systems, wild rice stands and macro-regional patterns. Journal of Archaeological Science, 51, 43-53.

Willis, J.C. 1915. VII. The endemic flora of Ceylon, with reference to geographical distribution and evolution in general. Philosophical Transactions of the Royal Society of London. Series B, Containing Papers of a Biological Character, 206 (325-334), 307-342.

Bouchaud, C., Thomas, R., Tengberg, M. (2012). Optimal use of the date palm (Phoenix dactylifera L.) during Antiquity anatomical identification of plant remains from Madâ in Sâlih (Saudi Arabia) Saguntum: Papeles del Laboratorio de Arqueología de Valencia, N ${ }^{\circ}$ Extra 13, pp. 173-186

Bradfield, J., Lombard, M., Wadley, L. 2015. Southern African arrow poison recipes, their ingredients and implications for Stone Age archaeology. Southern African Humanities, 27(1), 29-64.

Burger, P., Charrié-Duhaut, A., Connan, J., Albrecht, P., Flecker, M. 2010. The 9th-CenturyAD Belitung Wreck, Indonesia: analysis of a resin lump. International Journal of Nautical Archaeology, 39(2), 383-386.

Byrne, C., Dotte-Sarout, E., \& Winton, V. (2013). Charcoals as indicators of ancient tree and fuel strategies: An application of anthracology in the Australian Midwest. Australian Archaeology, 77, 94-106.

Byrne, C., Dooley, T., Manne, T., Paterson, A., Dotte-Sarout, E. (2020). Island survival: The anthracological and archaeofaunal evidence for colonial-era events on Barrow Island, northwest Australia. Archaeology in Oceania, 55(1), 15-32.

Cardon, D., Chatenet, G. D. 1990. Guide des teintures naturelles: plantes, lichens, champignons, mollusques et insectes. Delancahux et Niestlé ed. Paris.

Carswell, J., Deraniyagala, S., Graham, A. 2013. Mantai: city by the sea. Lindensoft-Verlag.

Carter, R. 2006. Boat remains and maritime trade in the Persian Gulf during the sixth and fifth millennia BC. Antiquity, 80(307), 52-63.

Charvat, P. 1993. External Contacts of Sri Lanka in the 1st Millennium AD (Archaeological evidence from Mantai). Archív orientální, 61, 13-29.

Coningham, R., Strickland, K., 2008. Sri Lanka. Encyclopedia of Archaeology 791-795.

Damblon, F. (Ed.) 2013. Proceedings of the Fourth International Meefing of Anthracology: Brussels, 8, 13th September 2008, Royal Belgian Institute of Natural Sciences. BAR International Series 2486, Oxford Archaeo Press 
Das, A. K., Islam, M. N., Faruk, M. O., Ashaduzzaman, M., Dungani, R., Rosamah, E., Hartati, S., Rumidatul, A. 2020. Hardwood Tannin: Sources, Utilizations, and Prospects. In: Aires, A. (Ed.) Tannins-Structural Properties, Biological Properties and Current Knowledge. IntechOpen.

Demicoli, M. 2015. Diachronic Study of Anthracological remains from the South Indian Site of Sannarachamma. Ms Thesis in Environmental Archaeology of University College London.

Deraniyagala, S.U. 1992. The Prehistory of Sri Lanka: an Ecological Perspective. Sri Lanka. Parts 1 and II. Purvidy Deprtamntuva. Dept. of Archaeological Survey, Govt. of Sri Lanka, Colombo.

Deraniyagala, S.U. 2004. Pre-Historic Basis for the Rise of Civilization in Sri Lanka and Southern India: Second Vesak Commemoration Lecture. Sri Lanka Deputy High Commission, Chennai.

Detienne, P., Jacquet, P. 1999. Manuel d'identification des bois de Polynésie. Cirad.

Devendra, S. 1999. Archaeology under Sri Lankan waters. Journal of the Royal Asiatic Society of Sri Lanka, 44, 49-71.

Devendra, S., Muthucumarana, R. 2013. Maritime Archaeology and Sri Lanka: globalization, immigration, and transformation in the underwater archaeological record. Historical Archaeology, 47(1), 50-65.

Dilhan, M. A. A. B., Yakandawala, D., Gunatilleke, C. V. S., Bambaradeniya, C. N. B. 2002. Structure and composition of a scrubland vegetation in the lower Walawe basin irrigation extension area in Sri Lanka. Ceylon Journal of Science (Biological Science), 30, 125-145.

Dotte-Sarout, E. 2010. "The ancestor wood": trees, forests and precolonial kanak settlement on New Caledonia Grande Terre: case study and anthracological approach in the Tiwaka Valley (Northeastern Grande Terre). PhD Dissertation. Université Paris I.

Dotte-Sarout, E. 2011. Evaluating methods and results for the application of anthracology to high diversity and high endemism environments: Case study in the Tiwaka Valley, northeastern Grande Terre of New Caledonia. SAGVNtVM Extra, 11, 41-42.

Dotte-Sarout, E. 2017. Evidence of forest management and arboriculture from wood charcoal data: an anthracological case study from two New Caledonia Kanak pre-colonial sites. Vegetation History and Archaeobotany, 26(2), 195-211.

Dotte-Sarout, E., Ouetcho, J., Bolé, J., Barret, D., Sand, C. 2013. Of charcoals and forests: Results and perspectives from an archaeobotanical investigation of precolonial kanak settlement sites in New Caledonia. Pacific archaeology: Documenting the past, 50, 120-137.

Dotte-Sarout, E., Carah, X., Byrne, C. 2015. Not just carbon: assessment and prospects for the application of anthracology in O ceania. Archaeology in Oceania, 50(1), 1-22. 
Dotte-Sarout, E., Kahn, J.G. 2017. Ancient woodlands of Polynesia: a pilot anthracological study on Maupiti Island, French Polynesia. Quaternary International, 457, 6-28.

Eichhorn, B., Neumann, K. 2016. Holocene vegetation change and land use at Ounjougou, Mali. In Archaeology of African plant use (pp. 83-96). Routledge.

Ekblom, A., Eichhorn, B., Sinclair, P., Badenhorst, S., Berger, A. 2014. Land use history and resource utilisation from ad. 400 to the present, at Chibuene, southern Mozambique. Vegetation history and archaeobotany, 23(1), 15-32.

Elevitch, C. 2006. Species profiles for Pacific island agroforestry. Cocos nucifera (palm family). April version 2.1. www.traditionaltree.org.

Erdelen, W. (1988). Forest ecosystems and nature conservation in Sri Lanka. Biological Conservation, 43(2), 115-135.

Erlandson J.M., Braje T.J. 2015. Coasting out of Africa: The potential of mangrove forests and marine habitats to facilitate human coastal expansion via the southern dispersal Route. Quaternary International, 382, 31-41.

Fathi, L., Frühwald, A., Koch, G. 2014. Distribution of lignin in vascular bundles of coconut wood (Cocos nucifera) by cellular UV-spectroscopy and relationship between lignification and tensile strength in single vascular bundles. Holzforschung, 68(8), 915-925.

Fiorentino, G., Magri, D. (Eds.). 2008. Charcoals from the Past: Cultural and Palaeoenvironmental Implications: Proceedings of the Third International Meeting of Anthracology, Cavallino, Lecce (Italy), June 28th-July 1st 2004 (Vol. 1807). British Archaeological Reports Limited.

Franke, G., Höhn, A., Schmidt, A., Ozainne, S., Breunig, P., Neumann, K., 2020. Pits, pots and plants at Pangwari - Deciphering the nature of a Nok Culture site. Azania Archaeological Research Africa, 55, 129-188.

Fuller, D.Q. 2002. Fifty years of archaeobotanical studies in India: laying a solid foundation. Indian archaeology in retrospect, 3, 247-363.

Fuller, D.Q. 2008. Domestication, diffusion and the development of agricultural villages: a study of the South Indian Neolithic. Egbert Forsten.

Fuller, D.Q., Harvey, E.L. 2006. The archaeobotany of Indian pulses: identification, processing and evidence for cultivation. Environmental archaeology, 11(2), 219-246.

Fuller, D.Q., Murphy, C. 2014. Overlooked but not forgotten: India as a center for agricultural domestication. General Anthropology, 21(2), 1-8.

Fuller, D.Q., Murphy, C. 2018. The origins and early dispersal of horsegram (Macrotyloma uniflorum), a major crop of ancient India. Genetic resources and crop evolution, 65(1), 285305. 
Fuller, D.Q, Korisettar, R., Venkatasubbaiah, P.C., Jones, M.K. 2004. Early plant domestications in southern India: some preliminary archaeobotanical results. Vegetation History and Archaeobotany, 13(2), 115-129.

Fuller, D.Q., Boivin, N., Korisettar, R. 2007. Dating the Neolithic of South India: new radiometric evidence for key economic, social and ritual transformations. Antiquity, 81(313), 755-778.

Fuller D.Q., Boivin, N., Hoogervorst, T., Allaby, R. 2011. Across the Indian Ocean: the prehistoric movement of plants and animals. Antiquity 85 (328), 544-558.

Gaur, A. S., Muthucumaran, R., Chandraratne, W. M., Orillandeda, B. C., Manders, M., Karunarathna, S., Karunarathna, S, Weerasinghe, P., Dayananda, AMA., Zainab, T., Sudaryadi, A., Ghani, KABA., Wahjudin, J., Samaraweera, N. 2011. Preliminary assessment of an early historic (2000-year-old) shipwreck at Godawaya, Sri Lanka. Journal of the Australasian Institute for Maritime Archaeology, 35, 9.

Ghosh, A., Schmidt, S., Fickert, T., Nüsser, M. 2015. The Indian Sundarban mangrove forests: history, utilization, conservation strategies and local perception. Diversity, 7(2), 149-169.

Goisan, L., Ponton, C., Usman, M., Blusztajn, J., Fuller, D., Galy, V., Haghipour, N., Johnson, J.E., McIntyre, C., Wacker, L., Eglinton, T. 2017. Short Communication: Massive Erosion in Monsoonal Central India Linked to Late Holocene Landcover Degradation, Earth Surface Dynamics 5,781-789.

Gokhale, S. B., Tatiya, A.U., Bakliwal, S.R., Fursule, R.A. 2004. Natural dye yielding plants, $3(4), 228-234$.

Guibal, F., Pomey, P. 2003. Timber supply and ancient naval architecture. In: Beltrane, C. (Ed.). Boats, Ships and Shipyards: Proceedings of the Ninth International Symposium on Boat and Ship Archaeology, Venice 2000. Oxbow Books Limited, pp. 35-41.

Gunawardana, R. 2003. Seaways to Sielediba. In: Bandaranayake, S., Dewaraja, L., Silva, R., Wimalaratne, KDG (Eds.), Sri Lanka and the Silk Road of the Sea, second ed. Sri Lanka Institute of International Relations, Colombo, pp. 17-35.

Guo, R., Wang, T., Zhou, G., Xu, M., Yu, X., Zhang, X., Feng Sui, F., Li, C., Tang, L.Wang, Z. 2018. Botany, phytochemistry, pharmacology and toxicity of Strychnos nux-vomica L.: a review. The American journal of Chinese medicine, 46(01), 1-23.

Hather, J.G. 1994. The identification of charred root and tuber crops from archaeological sites in the Pacific. In: Hather, J.G. (Ed.) Tropical archaeobotany: Applications and new developments, pp. 51-64.

Higham, C. F. (1996). A review of archaeology in Mainland Southeast Asia. Journal of Archaeological Research, 4(1), 3-49.

Höhn, A. (2007). Where did all the trees go? In: Cappers R (ed) Fields of change. Progress in African archaeobotany. Barkhuis Publishing, Eelde, Groningen, pp 35-42 
Höhn, A. 2018. Plants and People in the African Past: Themes and Objectives of Archaeobotany. Plants and People in the African Past: Progress in African Archaeobotany, 1.

Höhn A. K. Neumann 2017. Charcoal identification in a species-rich environment: The example of Dibamba, Cameroon. IAWA journal / International Association of Wood Anatomists 39(1):87-113.

Höhn, A., Neumann, K. 2018. Charcoal identification in a species-rich environment: The example of Dibamba, Cameroon. IAWA Journal, 39(1), 87-S47.

Höhn, A., Franke, G., Schmidt, A. 2018. Pits at Pangwari: Charcoal taphonomy at a multiphased Nok Site, central Nigeria. In Plants and People in the African Past (pp. 271-299). Springer, Cham.

Hubau, W., Van den Bulcke, J., Kitin, P., Mees, F., Van Acker, J., Beeckman, H. 2012. Charcoal identification in species-rich biomes: A protocol for Central Africa optimised for the Mayumbe forest. Review of Palaeobotany and Palynology, 171, 164-178.

InsideWood. 2004-onwards. Published on the Internet. http://insidewood.lib.ncsu.edu/search [used during 2018-2019].

Janaway, R.C., Coningham, R.A.E. 1995. A review of archaeological textile evidence from South Asia. South Asian Studies, 11(1), 157-174.

Jayatissa, L.P., Dahdouh-Guebas, F., Koedam, N. 2002. A review of the floral composition and distribution of mangroves in Sri Lanka. Botanical Journal of the Linnean Society, 138(1), 2943.

Kajale, M.D. 1989. Archaeobotanical investigation on megalithic Bhagimohari, and its significance for ancient Indian agricultural system. Man and Environment, 13(2), 87-100.

Kajale, M.D. 1990. Ancient plant economy from excavations at Mantai, district Mannar, northwest Sri Lanka. Ancient Ceylon, 12, 263-6.

Kajale, M.D. 1991. Current status of Indian palaeoethnobotany: introduced and indigenous food plants with a discussion of the historical and evolutionary development of Indian agriculture and agricultural systems in general. New Light on Early Farming. Edinburgh University Press, Edinburgh, 155-189.

Kajale, M.D. 1994. Archaeobotanical investigations on a multicultural site at Adam, Maharashtra, with special reference to the development of tropical agriculture in arts of India. In: Hather, J.G. (Ed.) Tropical archaeobotany: Applications and new developments, pp. 34-50.

Killmann, W., Fink D. 1996. Coconut Palm Stem Processing Technical Handbook. Dept. Furniture and Wooden Products Deutsche Gesellschaft für Technische Zusammenarbeit (GTZ) GmbH. http://www.fao.org/3/ag335e/AG335E00.htm\#TOC.

King, F., Dotte-Sarout, E. 2019. Wood charcoal analysis in tropical rainforest: a pilot study identifying firewood used at toxic nut processing sites in northeast Queensland, Australia. Vegetation history and archaeobotany, 28(2), 163-185. 
Kingwell-Banham, E. 2019. Dry, rainfed or irrigated? Reevaluating the role and development of rice agriculture in Iron Age-Early Historic South India using archaeobotanical approaches. Archaeological and Anthropological Sciences, 11(12), 6485-6500.

Kingwell-Banham, E., Fuller, D.Q. 2012. Shifting cultivators in South Asia: Expansion, marginalisation and specialisation over the Long-Term. Quaternary International 249, 84-95

Kingwell-Banham, E., Bohingamuwa, W., Perera, N., Adikari, G., Crowther, A., Fuller, D.Q., Boivin, N. 2018. Spice and rice: pepper, cloves and everyday cereal foods at the ancient port of Mantai, Sri Lanka. Antiquity, 92(366), 1552-1570.

Kuo-Huang, L. L., Huang, Y. S., Chen, S. S., Huang, Y.R. 2004. Growth stresses and related anatomical characteristics in coconut palm trees. IAWA Journal, 25(3), 297-310.

Lancelotti, C. (2018). 'Not all that burns is wood'. A social perspective on fuel exploitation and use during the Indus urban period (2600-1900 BC). PloS one, 13(3).

Ludemann, T., Nelle O. 2017a. Anthracology: local to global significance of charcoal science. Part I. Quaternary International, 457, 1-5.

Ludemann, T., Nelle O. (2017b) Anthracology: local to global significance of charcoal science Part II. Quaternary International, 458, 1-232

Ludemann, T., Nelle O. 2018. Anthracology: local to global significance of charcoal science. Part III. Quaternary International, 463, 219-424

May, P., Tuckson, M. 2000. The Traditional Pottery of Papua New Guinea. University of Hawaii Press.

Meena, P., Choudhary, S., Nehra, S. 2007. Tannin and Dyes from Plants. Nehra, S. (Ed.). Economic Botany. Pointer publishers, pp. 106.

Mehta, V. K., Sullivan, P. J., Walter, M. T., Krishnaswamy, J., DeGloria, S.D. 2008. Ecosystem impacts of disturbance in a dry tropical forest in southern India. Ecohydrology:Ecosystems, Land and Water Process Interactions, Ecohydrogeomorphology, 1(2), 149-160.

Mercader, J., Panger, M., Boesch, C. 2002. Excavation of a chimpanzee stone tool site in the African rainforest. Science, 296(5572), 1452-1455.

Morrison, K.D., 2016. From Millets to Rice (and Back Again?): Cuisine, Cultivation, and Health in Southern India. In: Walimbe, S.R., Schug, G.R. (Eds.), A Companion to South Asia in the Past. Wiley Blackwell, New York, Chapter 24, pp. 358-373

Murphy, C., Fuller, D.Q. 2017. Seed coat thinning during horsegram (Macrotyloma uniflorum) domestication documented through synchrotron tomography of archaeological seeds. Scientific reports, 7(1), 1-9.

Murphy, C., Weisskopf, A., Bohingamuwa, W., Adikari, G., Perera, N., Blinkhorn, J., Horton, M., Fuller, D.Q. Boivin, N. 2018. Early agriculture in Sri Lanka: New Archaeobotanical 
analyses and radiocarbon dates from the early historic sites of Kirinda and Kantharodai (Kandarodai). Archaeological Research in Asia, 16, 88-102.

Muthucumarana, R., Gaur, A. S., Chandraratne, W. M., Manders, M., Rao, B. R., Bhushan, R., Khedekar, V.D., Dayananda, A.M.A. 2014. An early historic assemblage offshore of Godawaya, Sri Lanka: evidence for early regional seafaring in South Asia. Journal of Maritime Archaeology, 9(1), 41-58.

Mvimi, M. 2019. Reconstruction of environments and plant use in Holocene Southern Africa: study of macrobotanical remains from Late Stone Age sites of Toteng (Botswana), Leopard Cave and Geduld (Namibia). PhD doctoral dissertation, Muséum national d'histoire naturelle, Paris.

Nandasena, S., Wickremasinghe, A. R., Sathiakumar, N. 2012. Biomass fuel use for cooking in Sri Lanka: analysis of data from national demographic health surveys. American journal of industrial medicine, 55(12), 1122-1128.

Neumann, K. 1992. The contribution of anthracology to the study of the late Quaternary vegetation history of the Mediterranean region and Africa. Bulletin de la Société Botanique de France. Actualités Botaniques, 139(2-4), 421-440.

Neumann, K., Bostoen, K., Höhn, A., Kahlheber, S., Ngomanda, A., Tchiengué, B. 2012. First farmers in the Central African rainforest: A view from southern Cameroon. Quaternary International, 249, 53-62.

Ogata, K., Fufii,T., Abe,H., Baas, P. 2008. Identification of the timbers of Southeast Asia and the Western Pacific. Kaiseisha press.

Parthsarathy, M. V., Klotz, L. H. 1976. Palm “wood” I. Anatomical aspects. Wood Science and Technology, 10(3), 215-229.

Pearsall, D.M. 2019. Conclusion: Investigating Ancient Lifeways Through Paleoethnobotany. In: Pearsall, D.M. (Ed.). Case Studies in Paleoethnobotany: Understanding Ancient Lifeways Through the Study of Phytoliths, Starch, Macroremains, and Pollen. Routledge, pp. 228-236.

Perera, N.P. 1975. A physiognomic vegetation map of Sri Lanka (Ceylon). Journal of Biogeography, 2 (3), 185-203.

Perera, G.A.D. 2001. The secondary forest situation in Sri Lanka: a review. Journal of Tropical Forest Science, 13(4), 768-785.

Perera, N., Kourampas, N., Simpson, I. A., Deraniyagala, S. U., Bulbeck, D., Kamminga, J., Perera, J., Fuller, D.Q., Szabo, K., Oliveira, N.V. 2011. People of the ancient rainforest: Late Pleistocene foragers at the Batadomba-lena rockshelter, Sri Lanka. Journal of human evolution, 61(3), 254-269.

Perera, A. 2012. Present status of dry-zone flora in Sri Lanka. The National Red List, 165-174.

Prasad, S., Anoop, A. Riedel, N. Sarkar, S. Menzel, P., Basavaiah, N., Krishnan, R. Fuller, D.Q. Plessen, B. Gaye, B. Röhl, U. Wilkes, H. Sachse, D. Sawant, R. Wiesner, M.G. Stebich 
M. 2014. Prolonged monsoon droughts and links to Indo-Pacific warm pool: A Holocene record from Lonar Lake, central India. Earth and Planetary Science Letters 391,171-182.

Premathilake, R., 2006. Relationship of environmental changes in Central Sri Lanka to possible prehistoric land-use and climate changes. Palaeogeography, Palaeoecology, Palaeoclimatology, 24 (3-4), 468-496.

Premathilake, R., Epitawatta, S., Nilsson, S., 1999. Pollen morphology of some selected plant species from Horton Plains, Sri Lanka. Grana 38 (5), 289-295.

Premathilake, R., Seneviratne, S., 2015. Cultural implication based on pollen from the ancient mortuary complex in Sri Lanka. Journal of Archaeological Science 53, 559-569.

Punrattanasin, N., Nakpathom, M., Somboon, B., Narumol, N., Rungruangkitkrai, N., Mongkholrattanasit, R. 2013. Silk fabric dyeing with natural dye from mangrove bark (Rhizophora apiculata Blume) extract. Industrial Crops and Products, 49, 122-129.

Roberts, P., Boivin, N., Petraglia, M. 2015. The Sri Lankan 'microlithic'tradition c. 38,000 to 3,000 years ago: tropical technologies and adaptations of Homo sapiens at the southern edge of Asia. Journal of World Prehistory, 28(2), 69-112.

Roberts, P., Boivin, N., Petraglia, M., Masser, P., Meece, S., Weisskopf, A., Silva, F., Korisettar, R., Fuller, D.Q. 2016. Local diversity in settlement, demography and subsistence across the southern Indian Neolithic-Iron Age transition: site growth and abandonment at Sanganakallu-Kupgal. Archaeological and Anthropological Sciences, 8(3), 575-599.

Roberts, P., Perera, N., Wedage, O., Deraniyagala, S., Perera, J., Eregama, S., Petraglia, M.D., Lee-Thorp, J. A. 2017. Fruits of the forest: Human stable isotope ecology and rainforest adaptations in Late Pleistocene and Holocene ( 36 to $3 \mathrm{ka})$ Sri Lanka. Journal of human evolution, 106, 102-118.

Roberts, P., Gillingwater, T. H., Lahr, M. M., Lee-Thorp, J., MacCallum, M., Petraglia, M., Wedage, O, Heenbanda, U., Wainnya-Laeto, U. 2018. Historical tropical forest reliance amongst the Wanniyalaeto (Vedda) of Sri Lanka: an isotopic perspective. Human Ecology, $46(3), 435-444$.

Russell-Smith, J., Karunaratne, N. S., Mahindapala, R. 2006. Rapid inventory of wild medicinal plant populations in Sri Lanka. Biological conservation, 132(1), 22-32.

Scheel-Ybert, R. 2000. Vegetation stability in the Southeastern Brazilian coastal area from 5500 to $140014 \mathrm{C}$ yr BP deduced from charcoal analysis. Review of Palaeobotany and Palynology, 110(1-2), 111-138.

Scheel-Ybert, R. 2002. Evaluation of sample reliability in extant and fossil assemblages. In: Thiébault, S. (Ed.). Charcoal analysis: methodological approaches, palaeoecological results and wood uses: proceedings of the Second International Meeting of Anthracology. Bar International Series, 1063, pp. 9-16. 
Scheel-Ybert, R., Beauclair, M., Buarque, A. 2014. The forest people: landscape and firewood use in the Araruama region, southeastern Brazil, during the late Holocene. Vegetation History and Archaeobotany, 23(2), 97-111.

Schmier, S., Hosoda, N., Speck, T. 2020. Hierarchical structure of the Cocos nucifera (Coconut) endocarp: functional morphology and its influence on fracture toughness. Molecules, 25(1), 223.

Searles, P.J. 1928. The most Valuable Tree in the World. The Scientific Monthly, Vol. 27, No. 3 (Sep., 1928), pp. 271-280

Seland, E.H. 2014. Archaeology of trade in the western Indian Ocean, 300 BC-AD 700. Journal of Archaeological Research, 22(4), 367-402.

Siriweera, W. I. 2002. History of Sri Lanka: from earliest times up to the sixteenth century. Dayavamsa Jayakodi Saha Samagama.

Solangaarachchi, R. 2011. Ancient Iron Smelting Technology and the Settlement Pattern in the Kiri Oya Basin in the Dry Zone of Sri Lanka. PhD dissertation, University of Florida.

Stahl, A. B. 2004. Political economic mosaics: archaeology of the last two millennia in tropical sub-Saharan Africa. Annual Revue of Anthropology, 33, 145-172.

Sudo, S. 1980. Some anatomical properties and density of the stem of coconut palm (Cocos nucifera), with consideration for pulp quality. IAWA Journal, 1(4), 161-171.

Thiébault, S. 2002. Charcoal analysis: methodological approaches, palaeoecological results and wood uses: proceedings of the Second International Meeting of Anthracology, Paris, September 2000 (Vol. 1063). British Archaeological Reports Limited.

Thomas. R. 2011. Anatomie comparée des palmiers - Identification assistée par ordinateur, applications en paléobotanique et en archéobotanique. $\mathrm{PhD}$ Thesis. Botanique. Museum national d'histoire naturelle - MNHN PARIS.

Thomas, R. 2013. Anatomy of the endemic palms of the Near and Middle East: archaeobotanical perspectives. Revue d'ethnoécologie 4, 1-15.

Thomas, R., De Franceschi, D. 2013. Palm stem anatomy and computer-aided identification: The Coryphoideae (Arecaceae). American Journal of Botany 100(2), 289-313.

Thompson, G.B. 1994. Wood charcoals from tropical sites: a contribution to methodology and interpretation. In: Hather, J.G. (Ed.) Tropical archaeobotany: Applications and new developments, pp. 9-29.

Tomlinson, P. B. (2006). The uniqueness of palms. Botanical Journal of the Linnean Society, 151(1), 5-14.

Tripati, S., Sujatha, M., Rao, R.V., Rao, K.S. 2005. Use of timber in shipbuilding industry: Identification and analysis of timber from shipwrecks off Goa coast, India. Current Science, 1022-1027. 
Tyagi, M. 2006. Commercial relations between north-India and_Sri Lanka in ancient period: a study. Proceedings of the Indian History Congress. 67, 106-117.

Venkateswaran, R., Parthasarathy, N. 2003. Tropical dry evergreen forests on the Coromandel coast of India: structure, composition and human disturbance. Ecotropica, 9(1-2), 45-58.

Vernet, J.-L. (Ed.) 1992. Les charbons de bois, les anciens écosystèmes et le rôle de l'homme. Bulletin de la Société Botanique de France, 139, 2-4, Société Botanique de France, Paris.

Vosmer, T., Potts, D. T., Naboodah, H. A., Hellyer, P. 2003. The naval architecture of early Bronze Age reed-built boats of the Arabian Sea. In: Potts, D.T., Al Naboodah, H., Nābūdah, H.M., Hellyer, P. (Eds.). Archaeology of the United Arab Emirates. Proceedings of the First International Conference on the Archaeology of the UAE. Trident press, pp. 152-7.

Warmington, E.H. 1928. The commerce between the Roman Empire and India. Cambridge: Cambridge University Press.

Weisskopf, A., Harvey, E., Kingwell-Banham, E., Kajale, M., Mohanty, R., Fuller, D.Q. 2014. Archaeobotanical implications of phytolith assemblages from cultivated rice systems, wild rice stands and macro-regional patterns. Journal of Archaeological Science, 51, 43-53.

Willis, J.C. 1915. VII. The endemic flora of Ceylon, with reference to geographical distribution and evolution in general. Philosophical Transactions of the Royal Society of London. Series B, Containing Papers of a Biological Character, 206 (325-334), 307-342.

Fig. 1. b) Map showing the location of the most significant sites in Sri Lanka including the sites studied in this research Mantai, Kantharodai and Kirinda b) Map showing the vegetation zones of Sri Lanka modified after Erdelen (1988) and Roberts et al. (2018).

Fig. 2. Images of the archaeological contexts. a. General view of Mantai; b. view of Mantai during the excavation (Photo: D.Q. Fuller); c general view of Kirinda test pit; $d$. flotation at Kirinda (Photo: C. Murphy); e. general view of Kantharodai excavation; e. stratigraphy at Kantharodai (Photo: W. Bohingamuwa).

Fig. 3. Charts showing relative values of the results categories including identified and non-identified fragments. Among the non-identified fragments there are 3 categories: undetermined existing taxa that correspond to cf.; undetermined new taxa corresponding to possible other taxa; undetermined corresponding to altered fragments or fragments that do not provide enough characters to be identified.

Fig. 4. Taxa diversity in the anthracological samples. a: taxa diversity per site phases; $b$ : taxa diversity per site units.

Fig. 5. Kirinda saturation curve based on occurrence of taxa in each phase. 
Fig. 6. Kirinda anthracological diagram based on relative values from the identified categories in Table 4 excluding the Euphorbiaceae/Apocynaceae category.

Fig. 7. Charts showing vegetation communities in Kirinda, Kantharodai and Mantai based on charcoal results relative values including the entire assemblage for each site.

Table 1. Type of sites and chronology and sample data including number of samples and number of charcoal fragments analysed.

Table 2. Distribution of vegetation types for the taxa that appear in each of the sites based on their ecological distribution according to Asouti and Fuller (2008).

Table 3. Anthracological results of Kantharodai.

Table 4. Anthracological results of Kirinda.

Table 5. Anthracological results from Mantai. 
Figure 1

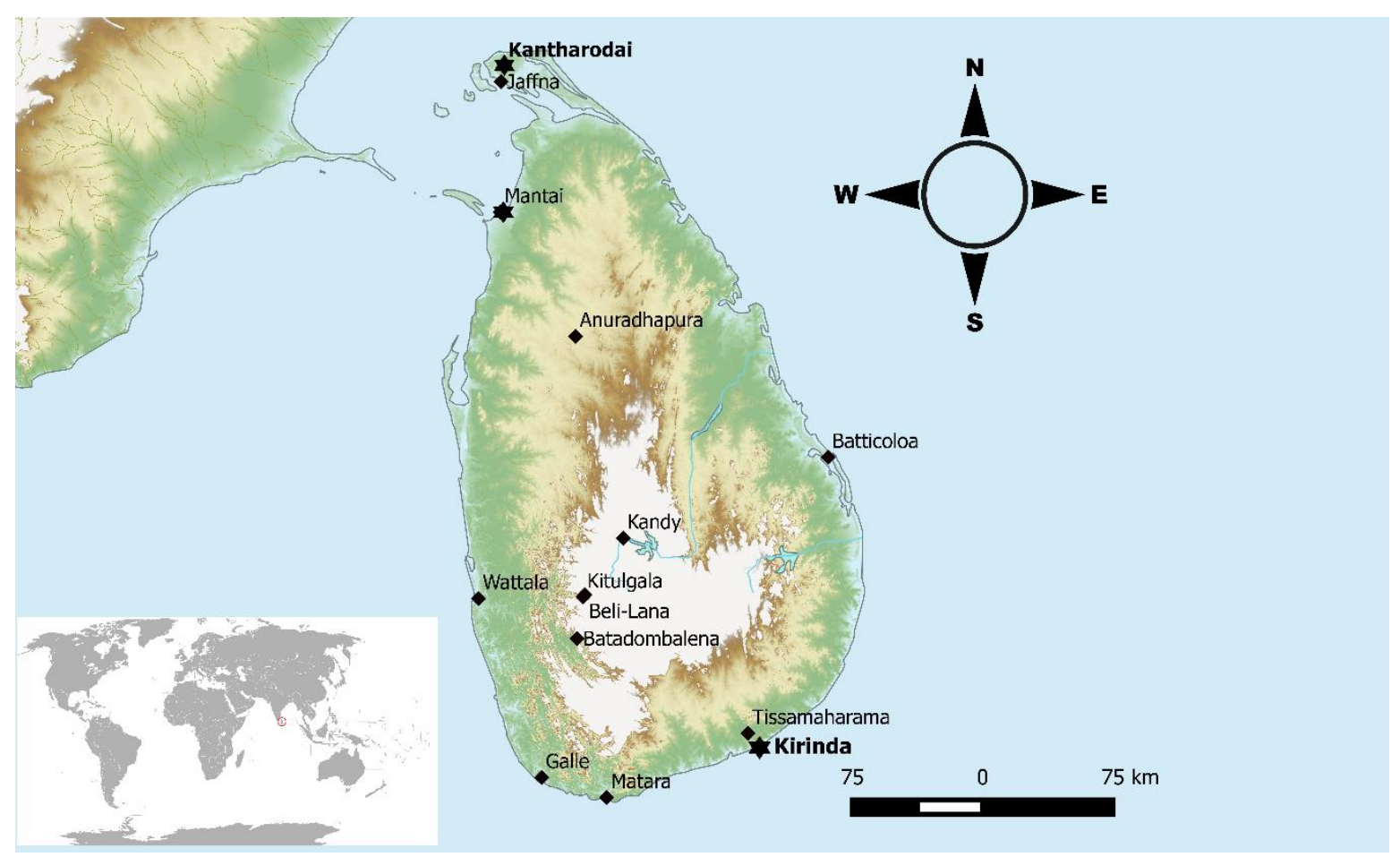

Figure 2 Site images

Figure 3

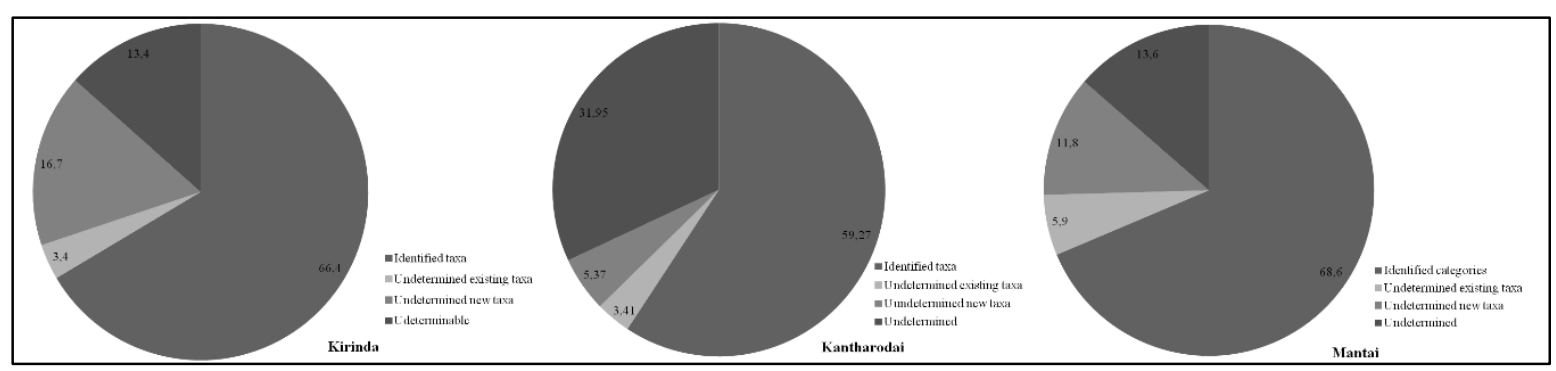


Figure 4

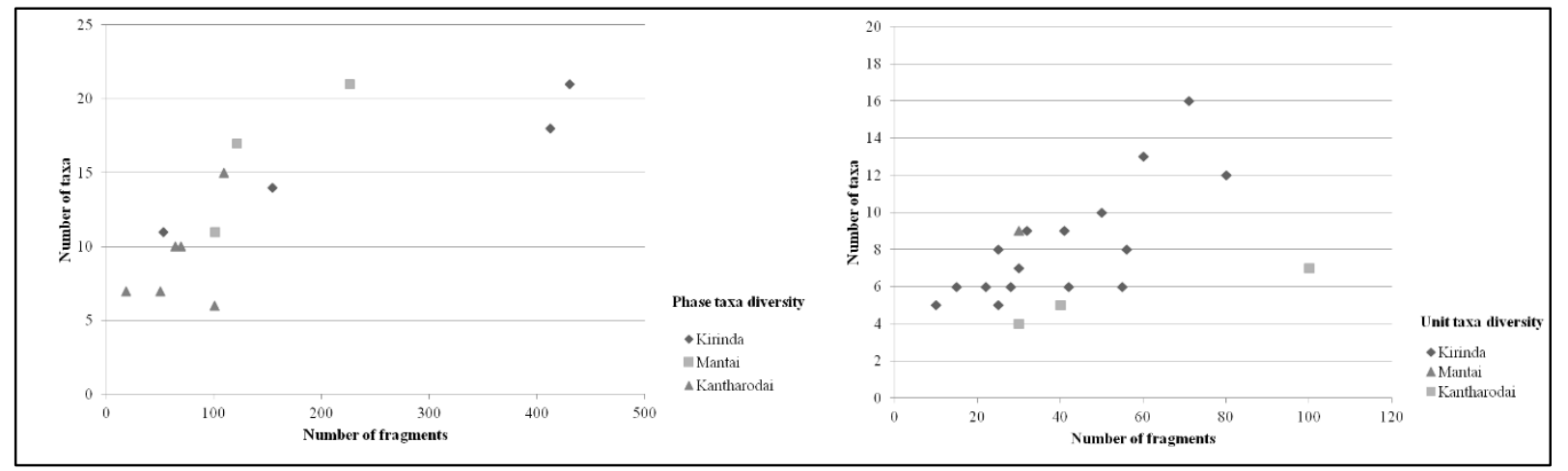

Figure 5

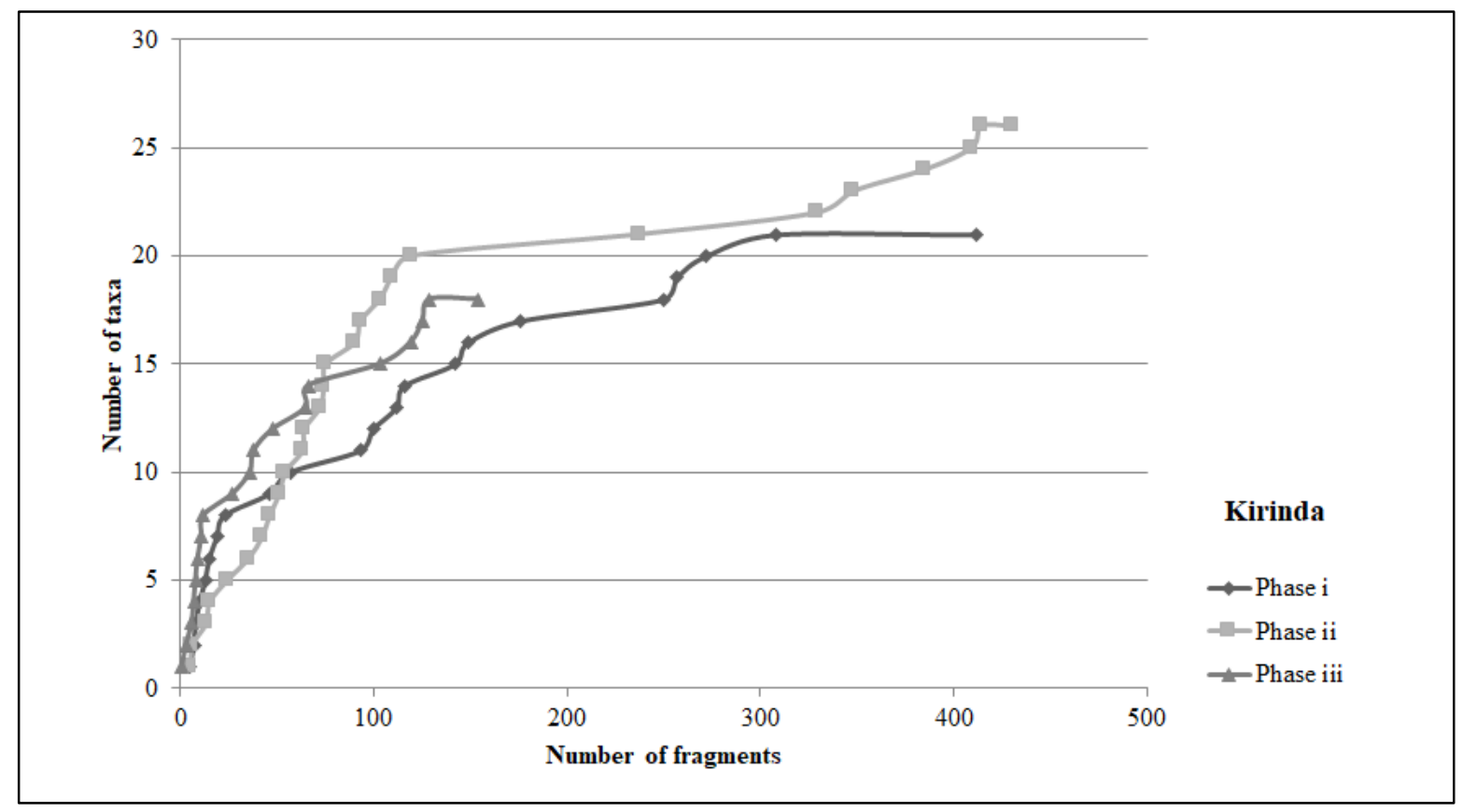

Figure 6

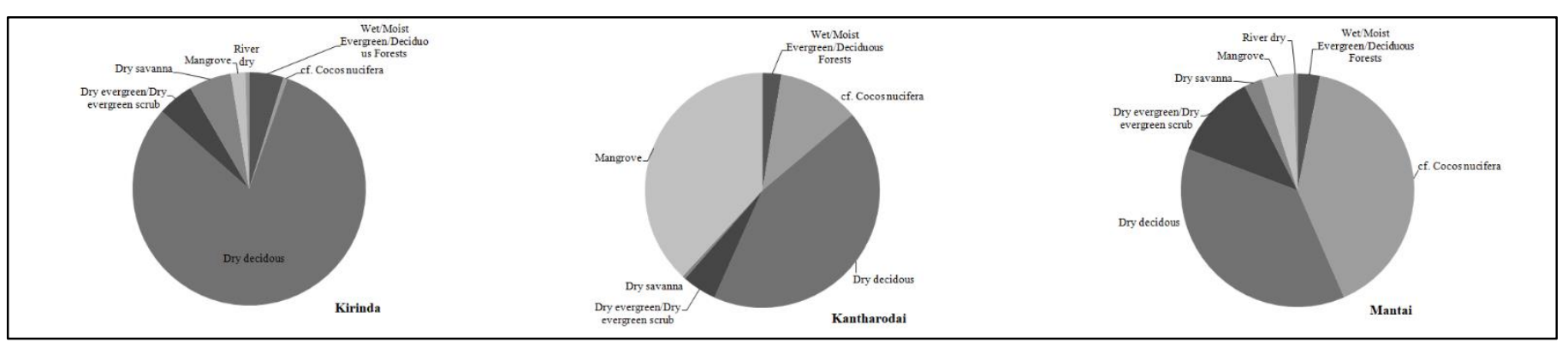




\begin{tabular}{|c|c|c|c|c|}
\hline & \multicolumn{2}{|c|}{ Kirinda } & Mantai & Kantharodai \\
\hline Type of site & \multicolumn{2}{|c|}{ Fishing settlement } & \multicolumn{2}{|c|}{ Urban } \\
\hline Period & \multicolumn{2}{|c|}{$500-900 \mathrm{AD}$} & $\begin{array}{l}200 \text { BCE- } 850 \\
\text { AD }\end{array}$ & 170-400 BCE \\
\hline Pit & KR03 & KR02 & & \\
\hline N. of samples & 32 & 8 & 28 & 15 \\
\hline N. of Phases & 3 & 1 & 2 & 6 \\
\hline N. of charcoal & 996 & 53 & 456 & 410 \\
\hline
\end{tabular}

Table 1. 
Table 2. Distribution based on Flora of Ceylon and Asouti and Fuller 2008. Not 100\% accurate for Sri lanka.

\begin{tabular}{|c|c|c|c|}
\hline Vegetation types & Kirinda & Kantharodai & Mantai \\
\hline $\begin{array}{l}\text { Wet/Moist } \\
\text { Evergreen/Deciduous } \\
\text { Forests }\end{array}$ & $\begin{array}{l}\text { Holigarnia, } \\
\text { Dipterocarpaceae, Ficus, } \\
\text { Vitex, Tectona, Albizia }\end{array}$ & Vitex, Tectona & Vitex, Ficus \\
\hline $\begin{array}{l}\text { Coast, wet and } \\
\text { Intermediate zones }\end{array}$ & cf. Cocos nucifera & cf. Cocos nucifera & cf. Cocos nucifera \\
\hline Dry decidous & $\begin{array}{l}\text { Wrightia, } \\
\text { Cassia/Tamarindus, } \\
\text { Dalbergia, Pterocarpus, } \\
\text { Strychnos, Meliaceae, } \\
\text { Ziziphus, Chloroxylon } \\
\text { swietenia, Tamarix, } \\
\text { Limonia acidissima }\end{array}$ & $\begin{array}{l}\text { Wrightia, } \\
\text { Cassia/Tamarindus, } \\
\text { Dalbergia, Pterocarpus, } \\
\text { Meliaceae, Ziziphus, } \\
\text { Ixora, Chloroxylon } \\
\text { swietenia, Santalum, } \\
\text { Limonia acidissima }\end{array}$ & $\begin{array}{l}\text { Wrightia, } \\
\text { Cassia/Tamarindus, } \\
\text { Dalbergia, Pterocarpus, } \\
\text { Strychnos, Meliaceae, } \\
\text { Ziziphus, Ixora, Santalum }\end{array}$ \\
\hline $\begin{array}{l}\text { Dry evergreen/Dry } \\
\text { evergreen scrub }\end{array}$ & $\begin{array}{l}\text { Acacia cf. leucophlea, } \\
\text { Albizia, } \\
\text { Canthium/Gardenia, } \\
\text { Polyalthia } \\
\end{array}$ & Canthium/Gardenia & $\begin{array}{l}\text { Acacia, } \\
\text { Canthium/Gardenia, } \\
\text { Morinda tinctoria, } \\
\text { Polyalthia } \\
\end{array}$ \\
\hline Dry savanna & Acacia, Acacia cf. nilotica & Acacia, Acacia cf. nilotica & Acacia, Acacia cf. nilotica \\
\hline Mangrove & Rhizophoraceae & Rhizophoraceae & Rhizophoraceae \\
\hline River dry & Tamarix & & \\
\hline
\end{tabular}


Table 3. Anthracological results of Kirinda

\begin{tabular}{|c|c|c|c|c|c|}
\hline \multirow[b]{2}{*}{ Families } & \multirow[b]{2}{*}{ Taxa } & \multicolumn{3}{|c|}{ KR03 } & \multirow{2}{*}{ KR02 } \\
\hline & & $\mathbf{i}$ & ii & iii & \\
\hline Anacardiaceae & Holigarnia & & & 1 & \\
\hline Annonaceae & Polyalthia & 1 & & 1 & \\
\hline Apocynaceae & Wrightia & 6 & 1 & 2 & 1 \\
\hline Arecaceae & cf. Cocos nucifera & & 1 & 2 & \\
\hline Buxaceae & Buxus & & & & 2 \\
\hline \multirow{2}{*}{ Combretaceae } & Anogeissus & & 1 & & \\
\hline & Terminalia & & 1 & & \\
\hline \multicolumn{2}{|l|}{ Dilleniaceae } & & 1 & & \\
\hline \multicolumn{2}{|c|}{ Dipterocarpaceae } & & 1 & & \\
\hline \multicolumn{2}{|c|}{ Euphorbiaceae/Apocynaceae } & 15 & 15 & 5 & \\
\hline \multirow{8}{*}{ Fabaceae } & Acacia & 10 & 15 & 9 & 10 \\
\hline & Acacia type leucopholea & 7 & 5 & 3 & \\
\hline & Acacia type nilotica & 9 & 9 & 8 & \\
\hline & Albizia & 1 & 5 & & \\
\hline & cf. Cassia/Tamarindus & 3 & 4 & & 1 \\
\hline & Dalbergia & 111 & 68 & 18 & 2 \\
\hline & Pterocarpus & 4 & 49 & 1 & 1 \\
\hline & Fabaceae & 18 & 32 & 10 & 1 \\
\hline Loganiaceae & Strychnos & 6 & 6 & & \\
\hline \multirow{3}{*}{ Meliaceae } & Azadirachta & & 1 & & \\
\hline & Soymida type & 1 & & 1 & \\
\hline & Meliaceae & 2 & 4 & 2 & \\
\hline \multirow{2}{*}{ Moraceae } & Ficus & 2 & & & \\
\hline & Moraceae & 1 & 2 & 3 & \\
\hline Myrtaceae & cf. Syzygium & & & 1 & \\
\hline Punicaceae & Punica granatum & & 1 & & \\
\hline Rhamnaceae & Ziziphus & 19 & 11 & 5 & 2 \\
\hline \multicolumn{2}{|l|}{ Rhizophoraceae } & 7 & 4 & & 1 \\
\hline \multirow{2}{*}{ Rubiaceae } & Canthium/Gardenia & 36 & 36 & 9 & 3 \\
\hline & Rubiaceae & 1 & 2 & & \\
\hline \multirow{2}{*}{ Rutaceae } & Chloroxylon swietenia & 3 & 2 & & \\
\hline & Limonia acidissima & 5 & 1 & & 1 \\
\hline Tamaricaceae & Tamarix & 2 & & & \\
\hline \multirow{2}{*}{ Verbenaceae } & Tectona cf. grandis & 3 & & 1 & 1 \\
\hline & Vitex & & 4 & & \\
\hline \multicolumn{2}{|c|}{ Total identified categories } & 224 & 226 & 66 & 29 \\
\hline
\end{tabular}


Table. 4. Table 4 Anthracological results of Kantharodai

\begin{tabular}{|c|c|c|c|c|c|c|c|c|}
\hline \multirow{2}{*}{\begin{tabular}{|l} 
Families \\
Apocynaceae \\
\end{tabular}} & \multirow{2}{*}{\begin{tabular}{|l} 
Taxa \\
Wrightia \\
\end{tabular}} & \multirow{2}{*}{$\begin{array}{c}\text { III } \\
5 \\
\end{array}$} & \multirow{2}{*}{ IV } & \multirow{2}{*}{$\begin{array}{l}\mathbf{V} \\
1 \\
\end{array}$} & \multicolumn{4}{|c|}{\begin{tabular}{l|l|l|l|} 
VI VII VII VII \\
\end{tabular}} \\
\hline & & & & & 1 & 4 & 1 & 2 \\
\hline Arecaceae & cf. Cocos nucifera & & 9 & 11 & 4 & & & 2 \\
\hline \multirow{5}{*}{ Fabaceae } & Acacia type nilotica & & 1 & & & & & \\
\hline & cf. Cassia/Tamarindus & & 2 & & & & & \\
\hline & Dalbergia & & 2 & & & & & \\
\hline & Pterocarpus & 3 & 4 & 2 & & 1 & & \\
\hline & Fabaceae & 1 & 2 & 1 & & 1 & & \\
\hline \multirow[t]{2}{*}{ Meliaceae } & Azadirachta & 1 & 6 & 1 & & & & 1 \\
\hline & Meliaceae & & & 2 & & & & \\
\hline \multicolumn{2}{|l|}{ Monocotyledon } & & 1 & 1 & & & & \\
\hline \multicolumn{2}{|l|}{ Moraceae } & & & & 1 & & & \\
\hline Rhamnaceae & Ziziphus & 3 & 2 & 1 & 2 & 1 & & \\
\hline \multicolumn{2}{|c|}{ Rhizophoraceae } & & 3 & & 83 & 1 & & 1 \\
\hline \multirow[t]{3}{*}{ Rubiaceae } & Canthium/Gardenia & 1 & 4 & & 3 & 1 & & 2 \\
\hline & Ixora & 1 & 1 & & & & & \\
\hline & Rubiaceae & & 1 & & & & & 3 \\
\hline \multirow[t]{2}{*}{ Rutaceae } & Chloroxylon swietenia & 9 & 20 & 3 & & & & 1 \\
\hline & Limonia acidissima & 2 & 1 & 2 & & 3 & & \\
\hline Santalaceae & cf. Santalum & 1 & 2 & 1 & & & & \\
\hline \multirow{2}{*}{ Verbenaceae } & Tectona cf. grandis & & & 1 & & & & \\
\hline & Vitex & 1 & 2 & & & 2 & & \\
\hline \multicolumn{2}{|c|}{ Total identified categories } & 29 & 66 & 27 & 94 & 14 & 1 & 12 \\
\hline
\end{tabular}


Table 5. Anthracological results from Mantai

\begin{tabular}{|c|c|c|c|}
\hline Families & Taxa & \begin{tabular}{|l|} 
Phase 1 \\
\end{tabular} & Phase 2 \\
\hline Annonaceae & Polyalthia & & 1 \\
\hline Apocynaceae & Wrightia & 8 & 3 \\
\hline Arecaceae & cf. Cocos nucifera & 31 & 34 \\
\hline \multirow{6}{*}{ Fabaceae } & Acacia & & 3 \\
\hline & Acacia type nilotica & 1 & 3 \\
\hline & cf. Cassia/Tamarindus & & 1 \\
\hline & Dalbergia & 1 & 2 \\
\hline & Fabaceae & 1 & 1 \\
\hline & Pterocarpus & & 3 \\
\hline Loganiceae & Strychnos & 3 & 6 \\
\hline \multirow[t]{2}{*}{ Meliaceae } & Azadirachta & & 1 \\
\hline & Meliaceae & & 16 \\
\hline \multirow[t]{2}{*}{ Monocotyledon } & Monocotyledon & 1 & \\
\hline & Moraceae & 2 & \\
\hline Rhamnaceae & Ziziphus & & 1 \\
\hline \multicolumn{2}{|l|}{ Rhizophoraceae } & 4 & 2 \\
\hline \multirow{3}{*}{ Rubiaceae } & Canthium/Gardenia & 5 & 8 \\
\hline & Ixora & 10 & 1 \\
\hline & Morinda tinctoria & 2 & \\
\hline Santalaceae & cf. Santalum & & 2 \\
\hline \multirow[t]{2}{*}{ Verbenaceae } & Vitex & 3 & 2 \\
\hline & Total & 96 & 121 \\
\hline
\end{tabular}




\section{Supplementary material}

Figure. 1A. Scanning Electron Microscope (Hitachi S-3400N) images of the charcoal taxa identified at Kirinda, Kantharodai and Mantai. Images were disposed on the stub using conducting carbon (LEITC) and they were afterwards gold covered (Quorum Q150RES). Descriptions are based on various atlases Parthsarathy and Klotz, 1976, Asouti and Fuller (2008), Ogata et al., (2008), Insidewood, (2004) and the images observations.

Holigarnia sp. (Anacardiaceae) (KR03 20_12). Present at Kirinda
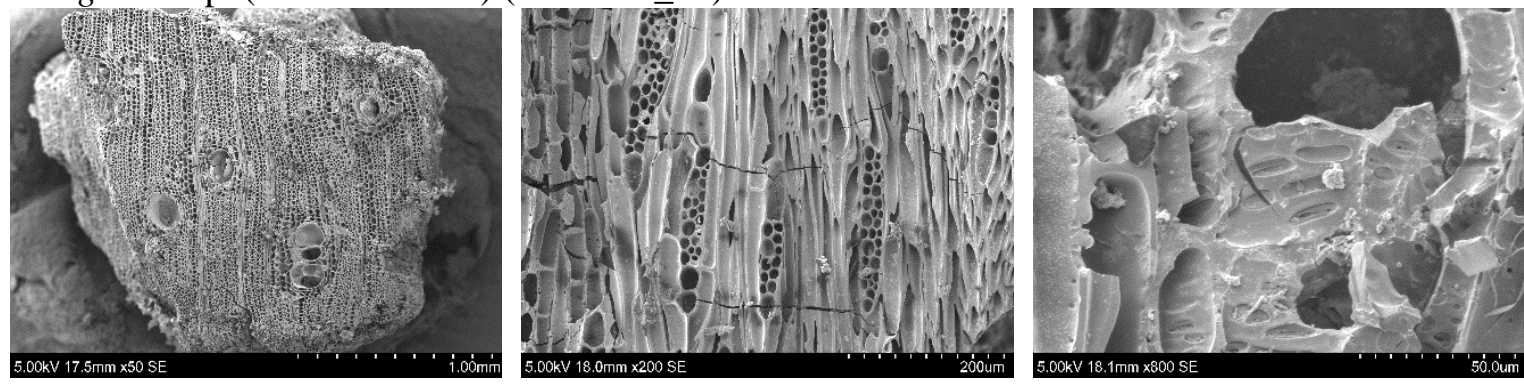

Diffuse porous, pores commonly solitary or in radial multiples of 2-3. Rays mostly biseriated and heterogeneous. Vessel-ray pits horizontal gash like

Arecaceae cf. Cocos nucifera (KR03 15_3). Present at Kirinda, Kantharodai and Mantai
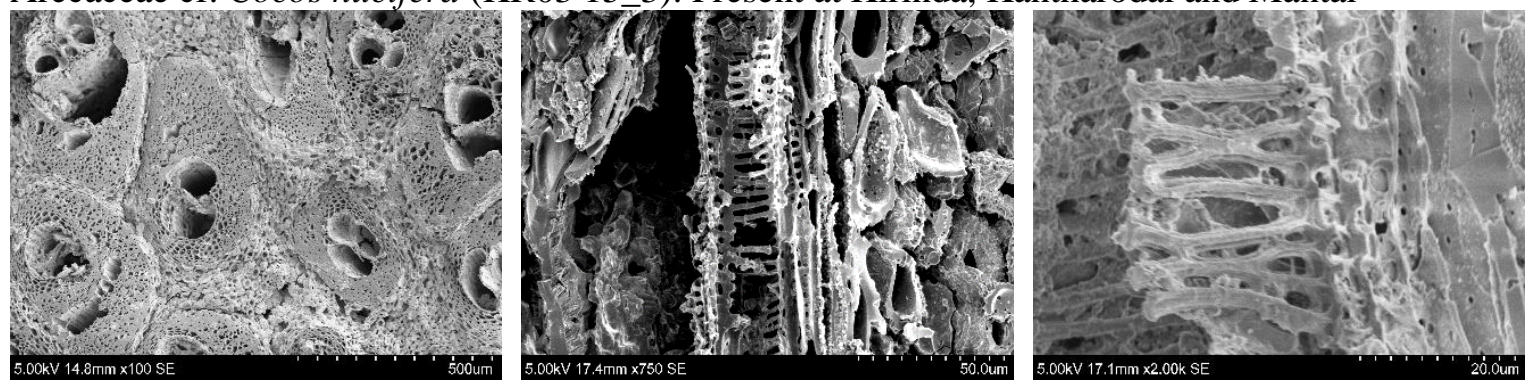

Dense vascular bundles. Vessel elements with scalariform pits.

Buxus sp. (Buxaceae) (KR02 10_4; 43_6). Present at Kirinda
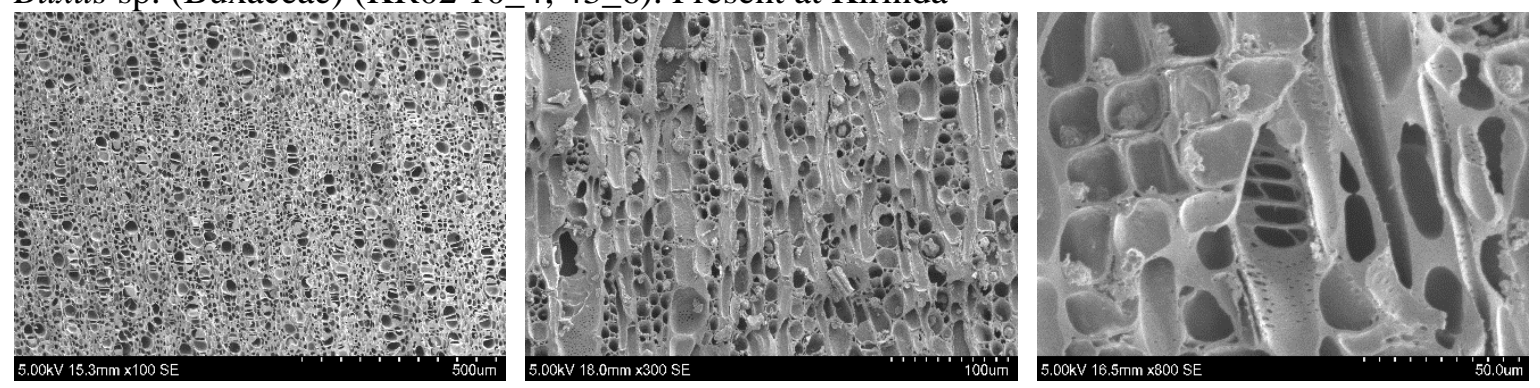

Diffuse Porous. Small pores, solitary or in radialmultiples. 2 seriated heterogenous rays. Scalariform perforations with 4- 5 bars. Small vessell pits. 
Acacia leucophlea type (Fabaceae) (KR03 37_15). Present at Kirinda.
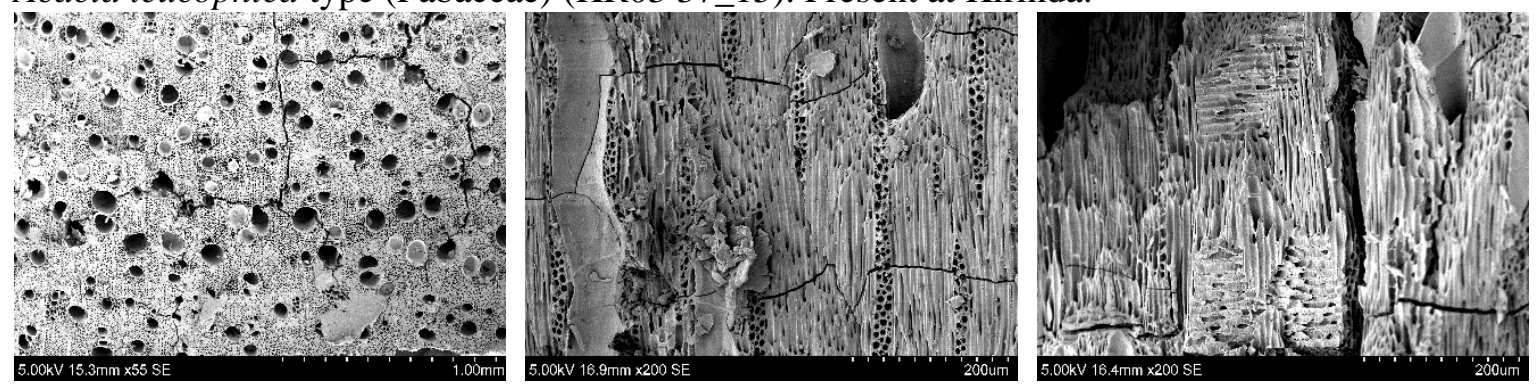

Transverse section: Diffuse-porous, medium to large mainly solitary. Parenchyma paratracheal aliform, confluent. Tangential and radial sections: 2-3 seriated homogeneous rays.

Acacia nilotica type (Fabaceae) (KR0319_7). Present at Kirinda, Kantharodai and Mantai
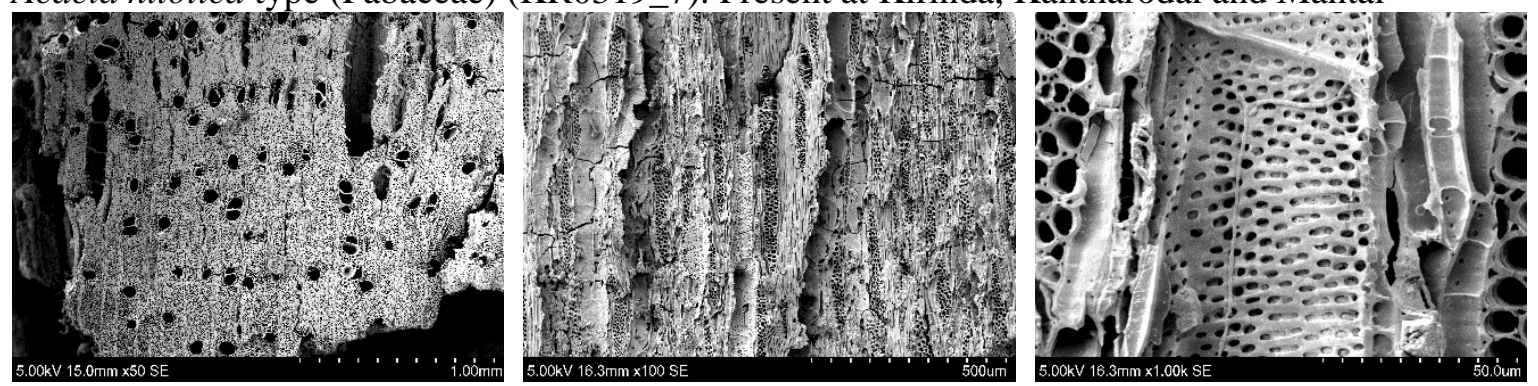

Transverse section: Diffuse-porous, medium to large mainly solitary. Parenchyma paratracheal aliform, confluent. Tangential and radial sections: 4-10 seriated homogeneous rays. Vestured pits present.

Dalbergia sp. (Fabaceae) (KR03_31_43_35). Present at Kirinda, Kanthrodai and Mantai
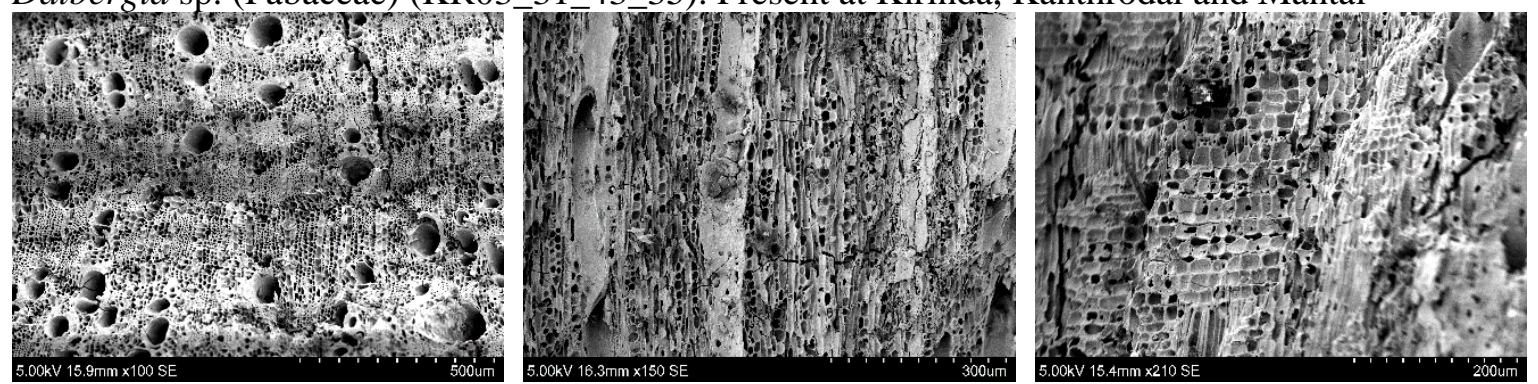

Transverse section: Diffuse-porous. Pores solitary or in radial multiples. Parenchyma banded and paratracheal. Tangential and radial sections: 1-2 seriated short rays. Rays homogeneous.

Pterocarpus sp. (Fabaceae) (KR03_36_1). Present at Kirinda, Kantharodai and Mantai
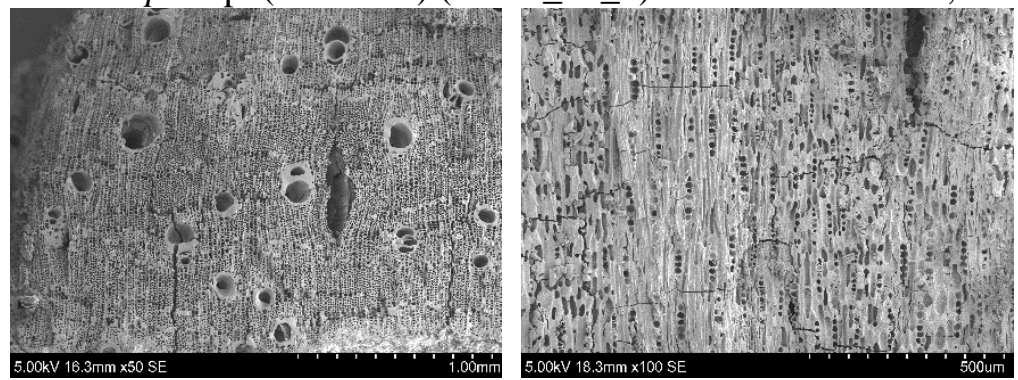

Transverse section: Diffuse-porous, pores solitary or in short radial multiples (2-3) or irregular clusters. Tangential sections: uniseriated storied rays. 
Strychnos sp. (Loganiceae) (KR03 34_37). Present at Kirinda and Mantai
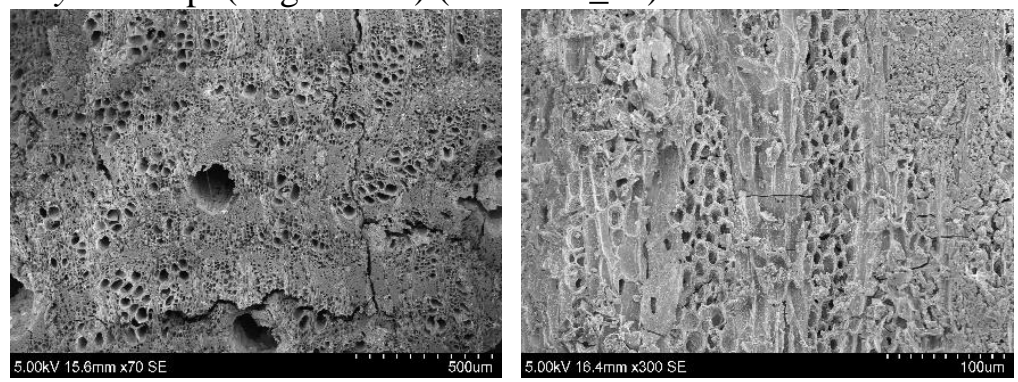

Diffuse-porous. Proes in radial multiples and clusters. Parenchyma paratracheal, apotracheal and banded. Inclded Phloem present. Rays mainly multiseriated with irregular shapes and heterogeneous.

Azadirachta sp. (Meliaceae) (KR03 17_8). Present at Kirinda, Kantharodai and Mantai
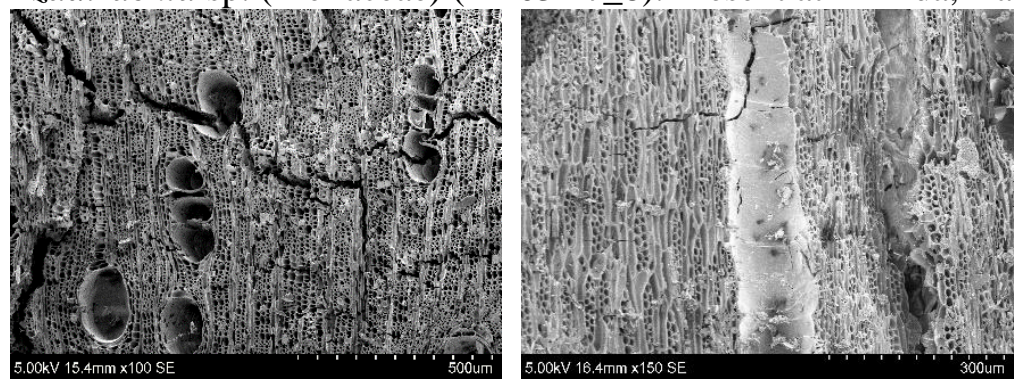

Diffuse porous. Pores medium large, solitary or in radial multiples of 2-4.Parenchyma apotracheal diffusse. Rays bi-seriated homogeneous.

Meliaceae cf. Soymida. (SLMA 31 36_1). Present at Kirinda
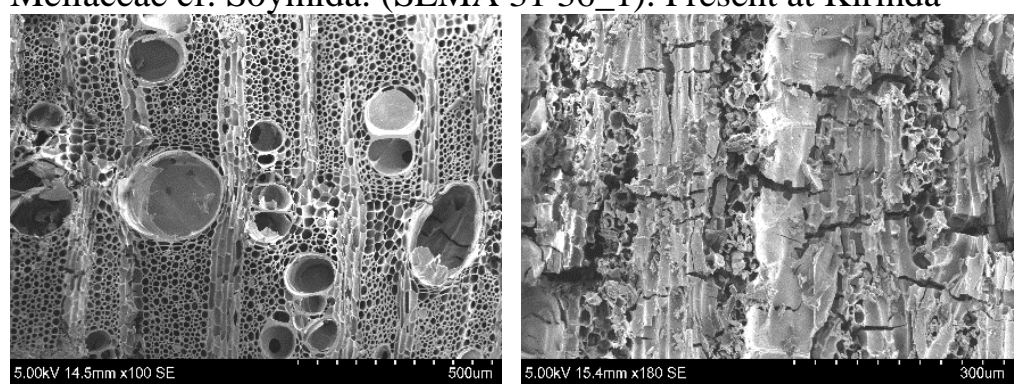

Diffuse porous. Pores medium to large solitary or in radial multiple clusters. Parenchyma paratracheal aliform and banded. Rays homogeneous to heterogeneous 3-5 seriated.

Ficus sp. (Moraceae) (KR03 19_4 \& KR03 19_22). Present at Kirinda. Moraceae family is present at Kirinda, Kantharodai and Mantai.
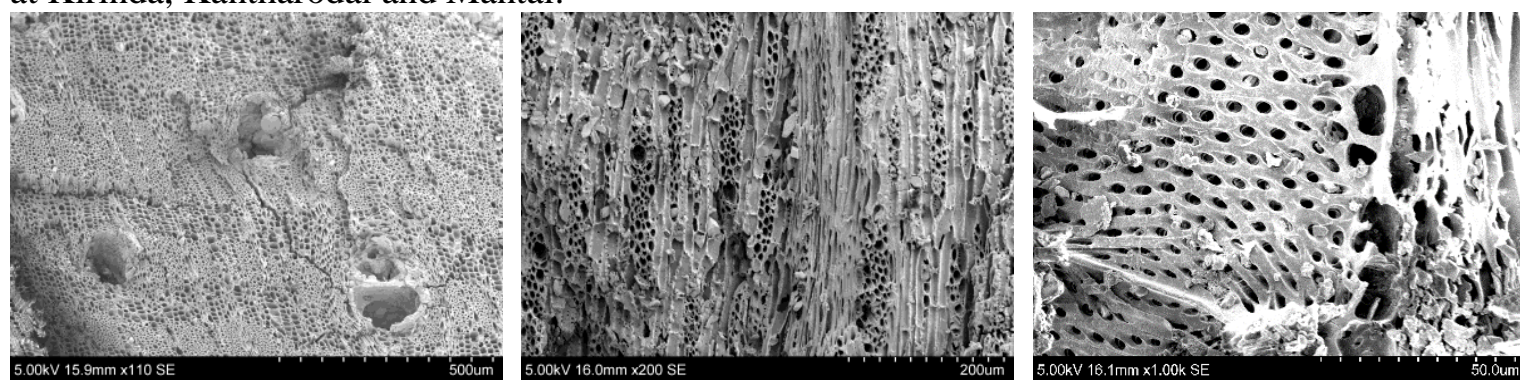

Transverse section Diffuse porous. Pores medium to large mostly solitary. Prenchyma banded. Multisearted rays 3-5 rays with sheath cells. 
Ziziphus sp. (Rhamnaceae) (KR03 43_27). Present at Kirinda, Kantharodai and Mantai
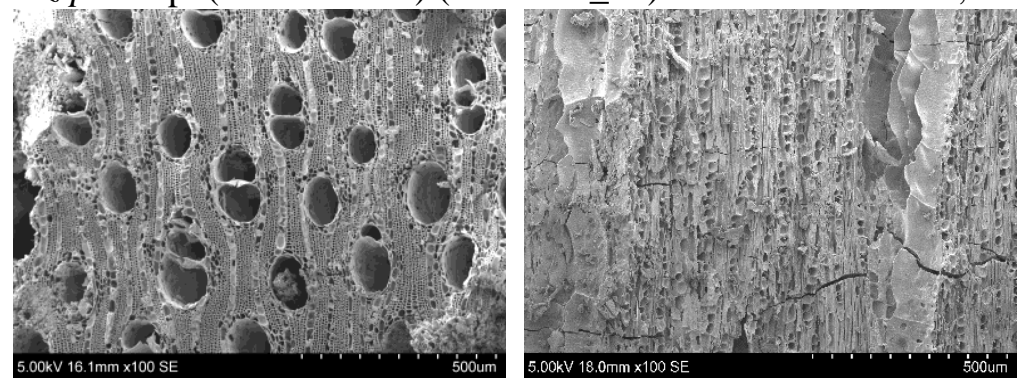

Diffuse porous. Pores medium to large isolated or in 2-3 radial multiples. Mostly uniseriated homogeneous rays

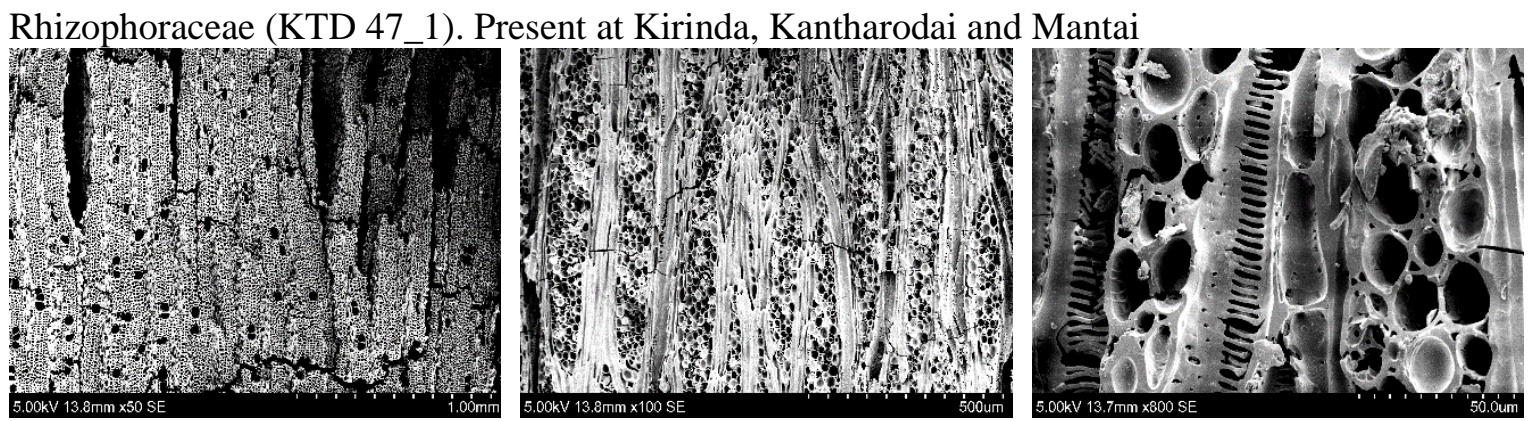

Diffuse porous. Small pores isolated or in 2 radial multiples. Multiseriated rays and scalariform

Canthium/Gardenia (Rubiaceae) (KR03 19_28). Present at Kirinda, Kantharodai and Mantai.
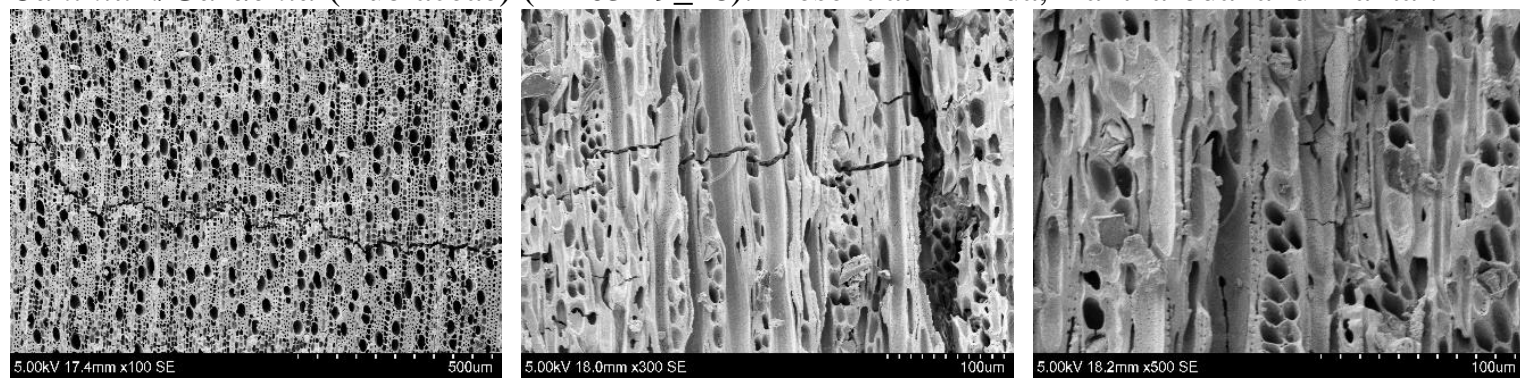

Diffuse porous. Pores small, mainly solitary. Parenchyma mainly apotracheal. Bi-seriated rays, conspicouisly heterogeneous with 2-4 rows of upright cells.

Ixora sp. (Rubiaceae) (SLMA52_6). Present at Kantharodai and Mantai.
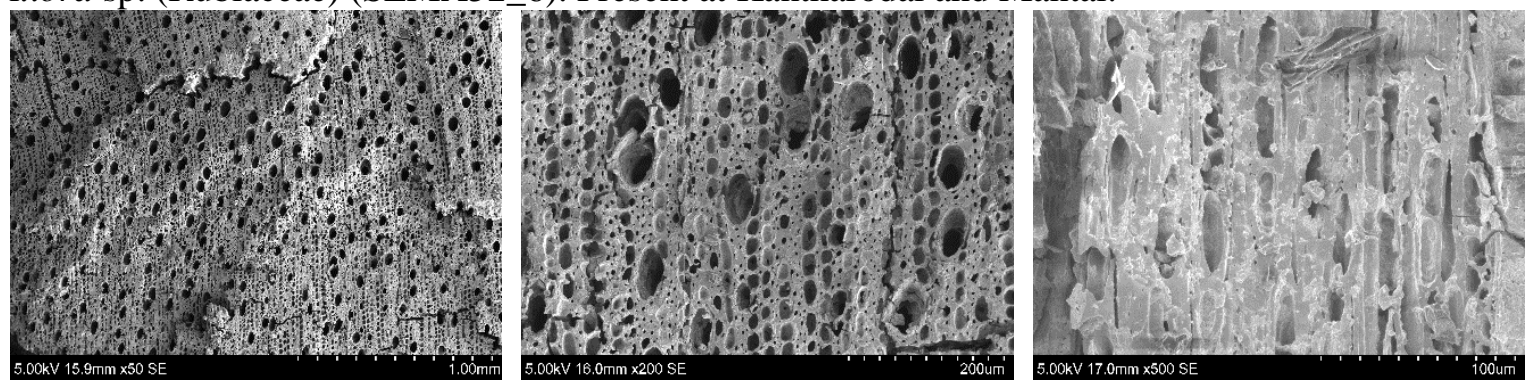

Diffuse porous. Pores small mainly solitary. Parenchyma mainly apotracheal. 1 to 2 seriated rays, conspicouisly heterogeneous with 2-4 rows of upright cells. Uniseriated rays composed only by upright cells. 
Morinda tinctoria (Rubiaceae) (SLMA49_7). Present at Kirinda.
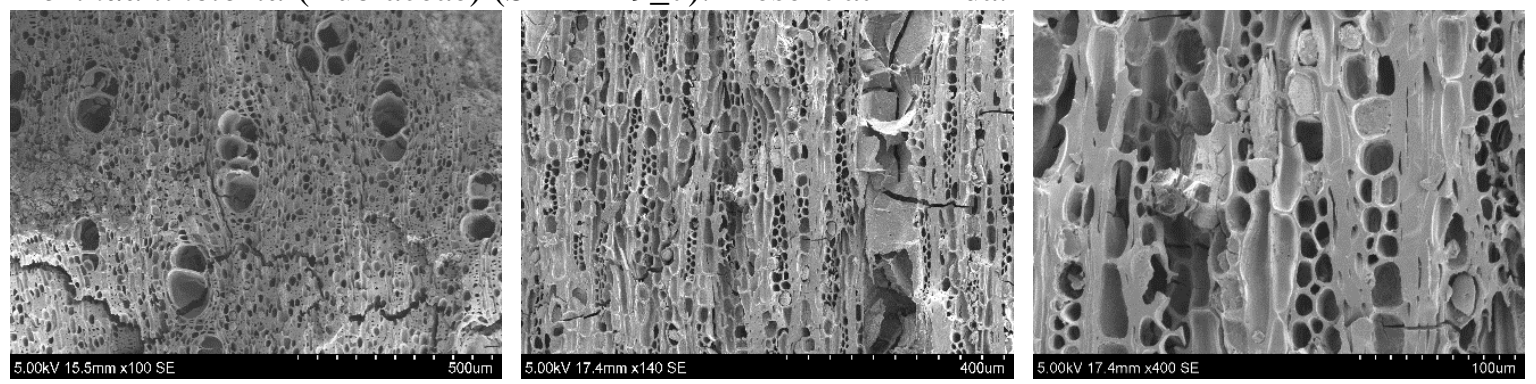

Diffuse porous. Pores small to medium, or in irregular clusters. Parenchyma apotracheal diffusse. Rays 1 to 3 seriate heterogeneous with upright marginal cells.

Chloroxylon swietenia (Rutaceae) (KTD 15_1). Present at Kirinda and Kantharodai.
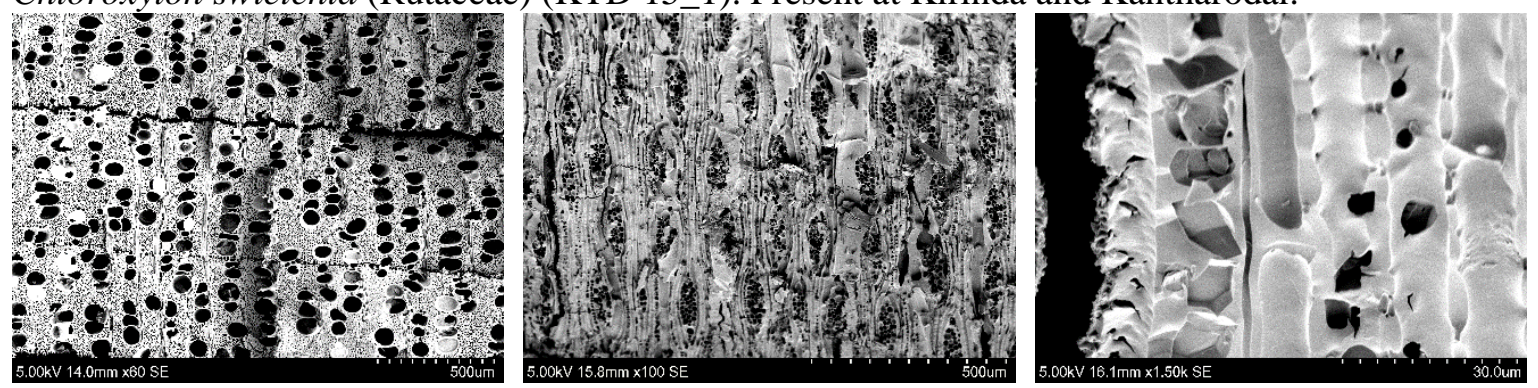

Diffuse to semiring porous. Pores medium, dense in radial multiples of 2 or more. Rays 3-4 seriated and heterogeneous. Rays storied.

Limonia acidissima (Rutaceae) (KR03 43_32). Present at Kirinda and Kantharodai.
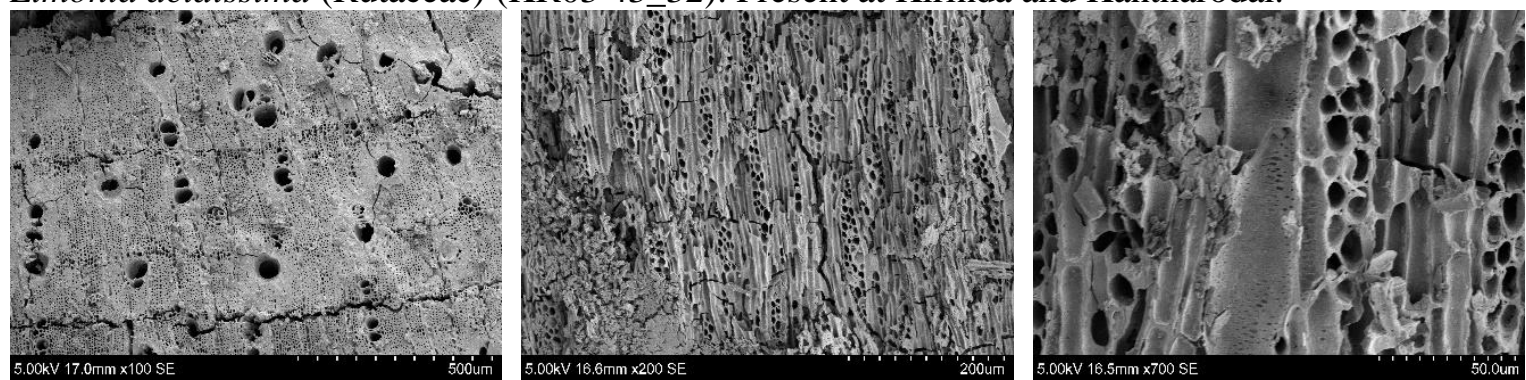

Diffuse porous. Pores small to medium solitary or radial multiple of 2-4 or clusters. Ray 2-3 seriated homogeneous.

Santalum sp. (Santalaceae) (KTD_37_1). Present at Kantharodai and Mantai

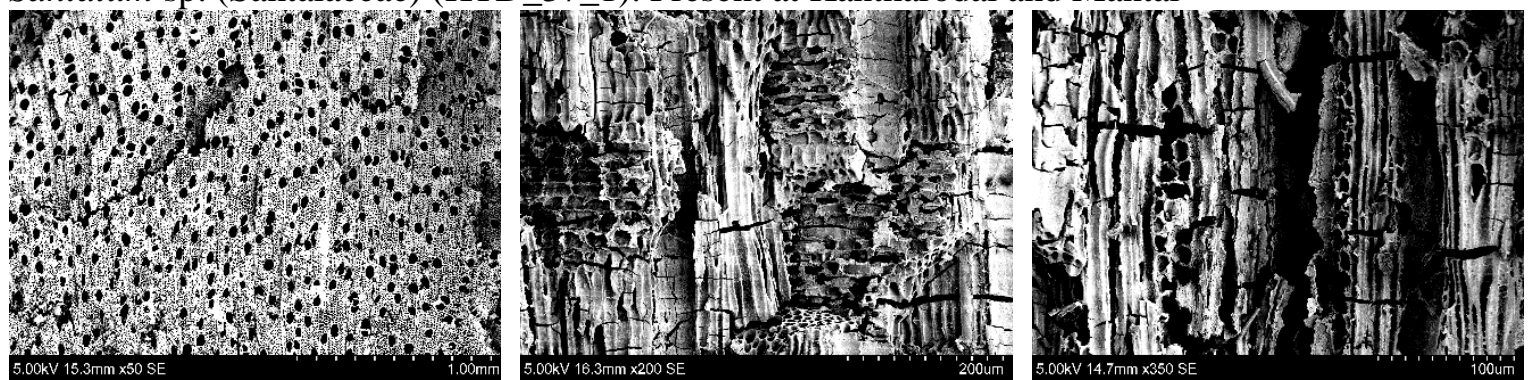

Diffuse porous. Pores small solitary. Rays heterogeneous with procumbent cells and 1-2 rows of square and/or upright marginal cells. 1-3 seriated and short. 
Tectona cf. grandis (Verbenaceae) (KR03 44_1). Present at Kirinda and Kantharodai
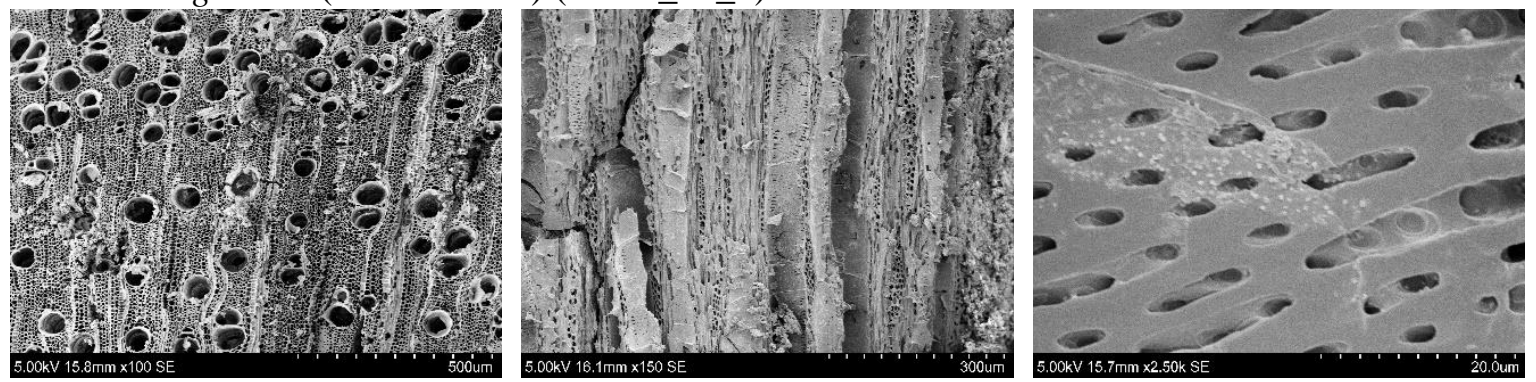

Ring to semi-ring porous. Pores solitary, in radial mutiples or irregular clusters. Rays 2-4 seriated homogeneous.

Vitex sp. (Verbenaceae) (KR03_32_5). Present at Kirinda, Kantharodai and Mantai
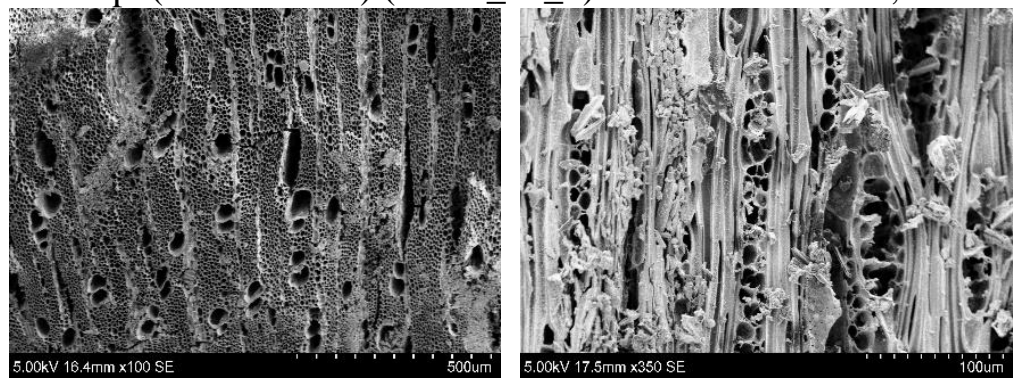

Diffuse porous. Pores small to medium communly solitary or in 2 radial multiples. Rays 2-3 seriarted homogeneous to heterougeneous with 1-2 rows of square and/or upright marginal cells. 